\title{
The green, blue and grey water footprint of crops and derived crop products
}

\author{
M. M. Mekonnen and A. Y. Hoekstra \\ Twente Water Centre, University of Twente, Enschede, The Netherlands \\ Received: 3 January 2011 - Published in Hydrol. Earth Syst. Sci. Discuss.: 20 January 2011 \\ Revised: 31 March 2011 - Accepted: 18 May 2011 - Published: 25 May 2011
}

\begin{abstract}
This study quantifies the green, blue and grey water footprint of global crop production in a spatially-explicit way for the period 1996-2005. The assessment improves upon earlier research by taking a high-resolution approach, estimating the water footprint of 126 crops at a 5 by 5 arc minute grid. We have used a grid-based dynamic water balance model to calculate crop water use over time, with a time step of one day. The model takes into account the daily soil water balance and climatic conditions for each grid cell. In addition, the water pollution associated with the use of nitrogen fertilizer in crop production is estimated for each grid cell. The crop evapotranspiration of additional $20 \mathrm{mi}-$ nor crops is calculated with the CROPWAT model. In addition, we have calculated the water footprint of more than two hundred derived crop products, including various flours, beverages, fibres and biofuels. We have used the water footprint assessment framework as in the guideline of the Water Footprint Network.

Considering the water footprints of primary crops, we see that the global average water footprint per ton of crop increases from sugar crops (roughly $200 \mathrm{~m}^{3} \mathrm{ton}^{-1}$ ), vegetables $\left(300 \mathrm{~m}^{3}\right.$ ton $\left.^{-1}\right)$, roots and tubers $\left(400 \mathrm{~m}^{3}\right.$ ton $\left.^{-1}\right)$, fruits $\left(1000 \mathrm{~m}^{3}\right.$ ton $\left.^{-1}\right)$, cereals $\left(1600 \mathrm{~m}^{3}\right.$ ton $\left.^{-1}\right)$, oil crops $\left(2400 \mathrm{~m}^{3}\right.$ ton $\left.^{-1}\right)$ to pulses $\left(4000 \mathrm{~m}^{3}\right.$ ton $\left.^{-1}\right)$. The water footprint varies, however, across different crops per crop category and per production region as well. Besides, if one considers the water footprint per kcal, the picture changes as well. When considered per ton of product, commodities with relatively large water footprints are: coffee, tea, cocoa, tobacco, spices, nuts, rubber and fibres. The analysis of water footprints of different biofuels shows that bio-ethanol has a lower water footprint (in $\mathrm{m}^{3} \mathrm{GJ}^{-1}$ ) than biodiesel, which supports earlier analyses. The crop used matters significantly
\end{abstract}

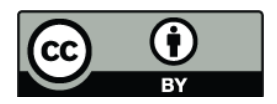

Correspondence to: M. M. Mekonnen (m.m.mekonnen@ctw.utwente.nl) as well: the global average water footprint of bio-ethanol based on sugar beet amounts to $51 \mathrm{~m}^{3} \mathrm{GJ}^{-1}$, while this is $121 \mathrm{~m}^{3} \mathrm{GJ}^{-1}$ for maize.

The global water footprint related to crop production in the period 1996-2005 was 7404 billion cubic meters per year ( $78 \%$ green, $12 \%$ blue, $10 \%$ grey). A large total water footprint was calculated for wheat $\left(1087 \mathrm{Gm}^{3} \mathrm{yr}^{-1}\right)$, rice $\left(992 \mathrm{Gm}^{3} \mathrm{yr}^{-1}\right)$ and maize $\left(770 \mathrm{Gm}^{3} \mathrm{yr}^{-1}\right)$. Wheat and rice have the largest blue water footprints, together accounting for $45 \%$ of the global blue water footprint. At country level, the total water footprint was largest for India $\left(1047 \mathrm{Gm}^{3} \mathrm{yr}^{-1}\right)$, China $\left(967 \mathrm{Gm}^{3} \mathrm{yr}^{-1}\right)$ and the USA $\left(826 \mathrm{Gm}^{3} \mathrm{yr}^{-1}\right)$. A relatively large total blue water footprint as a result of crop production is observed in the Indus river basin $\left(117 \mathrm{Gm}^{3} \mathrm{yr}^{-1}\right)$ and the Ganges river basin $\left(108 \mathrm{Gm}^{3} \mathrm{yr}^{-1}\right)$. The two basins together account for $25 \%$ of the blue water footprint related to global crop production. Globally, rain-fed agriculture has a water footprint of $5173 \mathrm{Gm}^{3} \mathrm{yr}^{-1}$ (91\% green, $9 \%$ grey); irrigated agriculture has a water footprint of $2230 \mathrm{Gm}^{3} \mathrm{yr}^{-1}$ (48\% green, $40 \%$ blue, $12 \%$ grey).

\section{Introduction}

Global freshwater withdrawal has increased nearly sevenfold in the past century (Gleick, 2000). With a growing population, coupled with changing diet preferences, water withdrawals are expected to continue to increase in the coming decades (Rosegrant and Ringler, 2000; Liu et al., 2008). With increasing withdrawals, also consumptive water use is likely to increase. Consumptive water use in a certain period in a certain river basin refers to water that after use is no longer available for other purposes, because it evaporated (Perry, 2007). Currently, the agricultural sector accounts for about $85 \%$ of global blue water consumption (Shiklomanov, 2000). 
The aim of this study is to estimate the green, blue and grey water footprint of crops and crop products in a spatiallyexplicit way. We quantify the green, blue and grey water footprint of crop production by using a grid-based dynamic water balance model that takes into account local climate and soil conditions and nitrogen fertilizer application rates and calculates the crop water requirements, actual crop water use and yields and finally the green, blue and grey water footprint at grid level. The model has been applied at a spatial resolution of 5 by 5 arc minute. The model's conceptual framework is based on the CROPWAT approach (Allen et al., 1998).

The concept of "water footprint" introduced by Hoekstra (2003) and subsequently elaborated by Hoekstra and Chapagain (2008) provides a framework to analyse the link between human consumption and the appropriation of the globe's freshwater. The water footprint of a product (alternatively known as "virtual water content") expressed in water volume per unit of product (usually $\mathrm{m}^{3}$ ton $^{-1}$ ) is the sum of the water footprints of the process steps taken to produce the product. The water footprint within a geographically delineated area (e.g. a province, nation, catchment area or river basin) is equal to the sum of the water footprints of all processes taking place in that area (Hoekstra et al., 2011). The blue water footprint refers to the volume of surface and groundwater consumed (evaporated) as a result of the production of a good; the green water footprint refers to the rainwater consumed. The grey water footprint of a product refers to the volume of freshwater that is required to assimilate the load of pollutants based on existing ambient water quality standards.

The water footprint is an indicator of direct and indirect appropriation of freshwater resources. The term "freshwater appropriation" includes both consumptive water use (the green and blue water footprint) and the water required to assimilate pollution (the grey water footprint). The grey water footprint, expressed as a dilution water requirement, has been recognised earlier by for example Postel et al. (1996) and Chapagain et al. (2006). Including the grey water footprint is relatively new in water use studies, but justified when considering the relevance of pollution as a driver of water scarcity. As stressed in UNDP's Human Development Report 2006, which was devoted to water, water consumption is not the only factor causing water scarcity; pollution plays an important role as well (UNDP, 2006). Pollution of freshwater resources does not only pose a threat to environmental sustainability and public health but also increases the competition for freshwater (Pimentel et al., 1997, 2004; UNEP GEMS/Water Programme, 2008). Vörösmarty et al. (2010) further argue that water pollution together with other factors pose a threat to global water security and river biodiversity.

There are various previous studies on global water use for different sectors of the economy, most of which focus on $w a-$ ter withdrawals. Studies of global water consumption (evaporative water use) are scarcer. There are no previous global studies on the grey water footprint in agriculture. L'vovich et al. (1990) and Shiklomanov (1993) estimated blue water consumption at a continental level. Postel et al. (1996) made a global estimate of consumptive use of both blue and green water. Seckler et al. (1998) made a first global estimate of consumptive use of blue water in agriculture at country level. Rockström et al. (1999) and Rockström and Gordon (2001) made some first global estimates of green water consumption. Shiklomanov and Rodda (2003) estimated consumptive use of blue water at county level. Hoekstra and Hung (2002) were the first to make a global estimate of the consumptive water use for a number of crops per country, but they did not explicitly distinguish consumptive water use into a green and blue component. Chapagain and Hoekstra (2004) and Hoekstra and Chapagain $(2007,2008)$ improved this study in a number of respects, but still did not explicitly distinguish between green and blue water consumption.

All the above studies are based on coarse spatial resolutions that treat the entire world, continents or countries as a whole. In recent years, there have been various attempts to assess global water consumption in agriculture at high spatial resolution. The earlier estimates focus on the estimation of blue water withdrawal (Gleick, 1993; Alcamo et al., 2007) and irrigation water requirements (Döll and Siebert, 2002). More recently, a few studies have separated global water consumption for crop production into green and blue water. Rost et al. (2008) made a global estimate of agricultural green and blue water consumption with a spatialresolution of 30 by 30 arc minute without showing the water use per crop, but applying 11 crop categories in the underlying model. Siebert and Döll $(2008,2010)$ have estimated the global green and blue water consumption for 24 crops and 2 additional broader crop categories applying a grid-based approach with a spatial-resolution of 5 by 5 arc minute. Liu et al. (2009) and Liu and Yang (2010) made a global estimate of green and blue water consumption for crop production with a spatial-resolution of 30 by 30 arc minute. Liu et al. (2009) distinguished 17 major crops, while Liu and Yang (2010) considered 20 crops and 2 additional broader crop categories. Hanasaki et al. (2010) present the global green and blue water consumption for all crops but assume one dominant crop per grid cell at a 30 by 30 arc minute resolution. In a recent study, Fader et al. (2011) made a global estimate of agricultural green and blue water consumption with a spatial-resolution of 30 by 30 arc minute, distinguishing 11 crop functional types.

\section{Method and data}

The green, blue and grey water footprints of crop production were estimated following the calculation framework of Hoekstra et al. (2011). The computations of crop evapotranspiration and yield, required for the estimation of the green and blue water footprint in crop production, have been done following the method and assumptions provided by Allen et 
al. (1998) for the case of crop growth under non-optimal conditions. The grid-based dynamic water balance model used in this study computes a daily soil water balance and calculates crop water requirements, actual crop water use (both green and blue) and actual yields. The model is applied at a global scale using a resolution of 5 by 5 arc minute (Mekonnen and Hoekstra, 2010). We estimated the water footprint of 146 primary crops and more than two hundred derived products. The grid-based water balance model was used to estimate the crop water use for 126 primary crops; for the other 20 crops, which are grown in only few countries, the CROPWAT 8.0 model was used.

The actual crop evapotranspiration $\left(\mathrm{ET}_{\mathrm{a}}, \mathrm{mm} \mathrm{day}^{-1}\right) \mathrm{de}-$ pends on climate parameters (which determine potential evapotranspiration), crop characteristics and soil water availability (Allen et al., 1998):

$$
\operatorname{ET}_{\mathrm{a}}[t]=K_{\mathrm{c}}[t] \times K_{\mathrm{s}}[t] \times \mathrm{ET}_{\mathrm{o}}[t]
$$

where $K_{\mathrm{c}}$ is the crop coefficient, $K_{\mathrm{S}}[t]$ a dimensionless transpiration reduction factor dependent on available soil water with a value between zero and one and $\mathrm{ET}_{0}[t]$ the reference evapotranspiration $\left(\mathrm{mm} \mathrm{day}^{-1}\right)$. The crop coefficient varies in time, as a function of the plant growth stage. During the initial and mid-season stages, $K_{\mathrm{c}}$ is a constant and equals $K_{\mathrm{c} \text {,ini }}$ and $K_{\mathrm{c} \text {,mid }}$ respectively. During the crop development stage, $K_{\mathrm{c}}$ is assumed to linearly increase from $K_{\mathrm{c}, \text { ini }}$ to $K_{\mathrm{c}, \text { mid }}$. In the late season stage, $K_{\mathrm{c}}$ is assumed to decrease linearly from $K_{\mathrm{c} \text {,mid }}$ to $K_{\mathrm{c} \text {,end }}$. Crop coefficients $\left(K_{\mathrm{c}}\right.$ 's) were obtained from Chapagain and Hoekstra (2004). Crop planting dates and lengths of cropping seasons were obtained from FAO (2008d), Sacks et al. (2010), Portmann et al. (2010) and USDA (1994). For some crops, values from Chapagain and Hoekstra (2004) were used. We have not considered multi-cropping practices. Monthly long-term average reference evapotranspiration data at 10 by 10 arc minute resolution were obtained from FAO (2008c). The 10 by 10 arc minute data were converted to 5 by 5 arc minute resolution by assigning the 10 by 10 minute data to each of the four 5 by 5 minute grid cells. Following the CROPWAT approach, the monthly average data were converted to daily values by curve fitting to the monthly average through polynomial interpolation.

The value of $K_{\mathrm{S}}$ is calculated on a daily basis as a function of the maximum and actual available soil moisture in the root zone.

$K_{\mathrm{S}}[t]=\left\{\begin{array}{cc}\frac{S[t]}{(1-p) \times S_{\max }[t]} \text { if } S[t]<(1-p) \times S_{\max }[t] \\ 1 & \text { Otherwise }\end{array}\right.$

where $S[t]$ is the actual available soil moisture at time $t$ (in $\mathrm{mm}) ; S_{\max }[t]$ the maximum available soil water in the root zone, i.e., the available soil water in the root zone when soil water content is at field capacity ( $\mathrm{mm}$ ); and $p$ the fraction of $S_{\max }$ that a crop can extract from the root zone without suffering water stress (dimensionless). Grid-based data on total available water capacity of the soil (TAWC) at a 5 by 5 arc minute resolution were taken from ISRIC-WISE (Batjes, 2006). An average value of TAWC of the five soil layers was used in the model.

In the case of rain-fed crop production, blue crop water use is zero and green crop water use $\left(\mathrm{m}^{3} \mathrm{ha}^{-1}\right)$ is calculated by summing up the daily values of $\mathrm{ET}_{\mathrm{a}}\left(\mathrm{mm} \mathrm{day}^{-1}\right)$ over the length of the growing period. In the case of irrigated crop production, the green and blue water use is calculated by performing two different soil water balance scenarios as proposed in Hoekstra et al. (2011) and also applied by FAO (2005), Siebert and Döll (2010) and Liu and Yang (2010). The first soil water balance scenario is carried out based on the assumption that the soil does not receive any irrigation, but using crop parameters of irrigated crops (such as rooting depth as under irrigation conditions). The second soil water balance scenario is carried out with the assumption that the amount of actual irrigation is sufficient to meet the irrigation requirement, applying the same crop parameters as in the first scenario. The green crop water use of irrigated crops is assumed to be equal to the actual crop evapotranspiration as was calculated in the first scenario. The blue crop water use is then equal to the crop water use over the growing period as simulated in the second scenario minus the green crop water use as estimated in the first scenario.

Crop growth and yield are affected by water stress. To account for the effect of water stress, a linear relationship between yield and crop evapotranspiration was proposed by Doorenbos and Kassam (1979):

$$
\left(1-\frac{Y_{\mathrm{a}}}{Y_{\mathrm{m}}}\right)=K_{\mathrm{y}}\left(1-\frac{\sum \mathrm{ET}_{\mathrm{a}}[t]}{\sum \mathrm{CWR}[t]}\right)
$$

where $K_{\mathrm{y}}$ is a yield response factor (water stress coefficient), $Y_{\mathrm{a}}$ the actual harvested yield $\left(\mathrm{kg} \mathrm{ha}^{-1}\right), Y_{\mathrm{m}}$ the maximum yield $\left(\mathrm{kg} \mathrm{ha}^{-1}\right), \mathrm{ET}_{\mathrm{a}}$ the actual crop evapotranspiration in $\mathrm{mm} /$ period and CWR the crop water requirement in $\mathrm{mm} \mathrm{period}^{-1}$ (which is equal to $K_{\mathrm{c}} \times \mathrm{ET}_{0}$ ). $K_{\mathrm{y}}$ values for individual periods and the complete growing period are given in Doorenbos and Kassam (1979). The maximum yield values for each crop were obtained by multiplying the corresponding national average yield values by a factor of 1.2 (Reynolds et al., 2000). The actual yields, which are calculated per grid cell, are averaged over the nation and compared with the national average yield data (for the period 1996 2005) obtained from FAO (2008a). The calculated yield values are scaled to fit the national average FAO yield data.

The green and blue water footprints of primary crops $\left(\mathrm{m}^{3}\right.$ ton $\left.^{-1}\right)$ are calculated by dividing the total volume of green and blue water use $\left(\mathrm{m}^{3} \mathrm{yr}^{-1}\right)$, respectively, by the quantity of the production (ton $\mathrm{yr}^{-1}$ ).

The grey water footprint is calculated by quantifying the volume of water needed to assimilate the nutrients that reach ground- or surface water. Nutrients leaching from agricultural fields are a main cause of non-point source pollution 
of surface and subsurface water bodies. In this study we have quantified the grey water footprint related to nitrogen use only. The grey component of the water footprint $\left(\mathrm{m}^{3}\right.$ ton $\left.^{-1}\right)$ is calculated by multiplying the fraction of nitrogen that leaches or runs off by the nitrogen application rate $\left(\mathrm{kg} \mathrm{ha}^{-1}\right)$ and dividing this by the difference between the maximum acceptable concentration of nitrogen $\left(\mathrm{kg} \mathrm{m}^{-3}\right)$ and the natural concentration of nitrogen in the receiving water body $\left(\mathrm{kg} \mathrm{m}^{-3}\right)$ and by the actual crop yield (ton ha ${ }^{-1}$ ). Country-specific nitrogen fertilizer application rates by crop have been estimated based on Heffer (2009), FAO (2006, 2009) and IFA (2009). Since grid-based fertilizer application rates are not available, we have assumed that crops receive the same amount of nitrogen fertilizer per hectare in all grid cells in a country. We have further assumed that on average $10 \%$ of the applied nitrogen fertilizer is lost through leaching, following Chapagain et al. (2006). The recommended maximum value of nitrate in surface and groundwater by the World Health Organization and the European Union is $50 \mathrm{mg}$ nitrate $\left(\mathrm{NO}_{3}\right)$ per litre and the maximum value recommended by US-EPA is $10 \mathrm{mg}$ per litre measured as nitrate-nitrogen $\left(\mathrm{NO}_{3}-\mathrm{N}\right)$. In this study we have used the standard of $10 \mathrm{mg}$ per litre of nitrate-nitrogen $\left(\mathrm{NO}_{3}-\mathrm{N}\right)$, following again Chapagain et al. (2006). Because of lack of data, the natural nitrogen concentrations were assumed to be zero.

The water footprints of crops as harvested have been used as a basis to calculate the water footprints of derived crop products based on product and value fractions and water footprints of processing steps following the method as in Hoekstra et al. (2011). For the calculation of the water footprints of derived crop products we used product and value fraction. Most of these fractions have been taken from FAO (2003) and Chapagain and Hoekstra (2004). The product fraction of a product is defined as the quantity of output product obtained per quantity of the primary input product. The value fraction of a product is the ratio of the market value of the product to the aggregated market value of all the products obtained from the input product (Hoekstra et al., 2011). Products and by-products have both a product fraction and value fraction. On the other hand, residues (e.g. bran of crops) have only a product fraction and we have assumed their value fraction to be close to zero.

The water footprint per unit of energy for ethanol and biodiesel producing crops was calculated following the method as applied in Gerbens-Leenes et al. (2009). Data on the dry mass of crops, the carbohydrate content of ethanol providing crops, the fat content of biodiesel providing crops and the higher heating value of ethanol and biodiesel were taken from Gerbens-Leenes et al. (2008a, b) and summarized in Table 1.

Monthly values for precipitation, number of wet days and minimum and maximum temperature for the period 19962002 with a spatial resolution of 30 by 30 arc minute were obtained from CRU-TS-2.1 (Mitchell and Jones, 2005). The 30 by 30 arc minute data were assigned to each of the thirty- six 5 by 5 arc minute grid cells contained in the 30 by 30 arc minute grid cell. Daily precipitation values were generated from the monthly average values using the CRU-dGen daily weather generator model (Schuol and Abbaspour, 2007).

Crop growing areas on a 5 by 5 arc minute grid cell resolution were obtained from Monfreda et al. (2008). For countries missing grid data in Monfreda et al. (2008), the MICRA2000 grid database as described in Portmann et al. (2010) was used to fill the gap. The harvested crop areas as available in grid format were aggregated to a national level and scaled to fit national average crop harvest areas for the period 1996-2005 obtained from FAO (2008a).

Grid data on the irrigated fraction of harvested crop areas for 24 major crops were obtained from the MICRA2000 database (Portmann et al., 2010). For the other 102 crops considered in the current study, we used the data for "other perennial" and "other annual crops" as in the MICRA2000 database, depending on whether the crop is categorised under "perennial" or "annual" crops.

\section{Results}

\subsection{The global picture}

The global water footprint of crop production in the period 1996-2005 was $7404 \mathrm{Gm}^{3} \mathrm{yr}^{-1}$ (78\% green, $12 \%$ blue, and $10 \%$ grey). Wheat takes the largest share in this total volume; it consumed $1087 \mathrm{Gm}^{3} \mathrm{yr}^{-1}$ (70\% green, $19 \%$ blue, $11 \%$ grey). The other crops with a large total water footprint are rice $\left(992 \mathrm{Gm}^{3} \mathrm{yr}^{-1}\right)$ and maize $\left(770 \mathrm{Gm}^{3} \mathrm{yr}^{-1}\right)$. The contribution of the major crops to the global water footprint related to crop production is presented in Fig. 1. The global average green water footprint related to crop production was $5771 \mathrm{Gm}^{3} \mathrm{yr}^{-1}$, of which rain-fed crops use $4701 \mathrm{Gm}^{3} \mathrm{yr}^{-1}$ and irrigated crops use $1070 \mathrm{Gm}^{3} \mathrm{yr}^{-1}$. For most of the crops, the contribution of green water footprint toward the total consumptive water footprint (green and blue) is more than $80 \%$. Among the major crops, the contribution of green water toward the total consumptive water footprint is lowest for date palm (43\%) and cotton (64\%). The global average blue water footprint related to crop production was $899 \mathrm{Gm}^{3} \mathrm{yr}^{-1}$. Wheat $\left(204 \mathrm{Gm}^{3} \mathrm{yr}^{-1}\right)$ and rice $\left(202 \mathrm{Gm}^{3} \mathrm{yr}^{-1}\right)$ have large blue water footprint together accounting for $45 \%$ of the global blue water footprint. The grey water footprint related to the use of nitrogen fertilizer in crops cultivation was $733 \mathrm{Gm}^{3} \mathrm{yr}^{-1}$. Wheat $\left(123 \mathrm{Gm}^{3} \mathrm{yr}^{-1}\right)$, maize $\left(122 \mathrm{Gm}^{3} \mathrm{yr}^{-1}\right)$ and rice $\left(111 \mathrm{Gm}^{3} \mathrm{yr}^{-1}\right)$ have large grey water footprint together accounting for about $56 \%$ of the global grey water footprint.

The green, blue, grey and total water footprints of crop production per grid cell are shown in Fig. 2. Large water footprints per grid cell $\left(>400 \mathrm{~mm} \mathrm{yr}^{-1}\right)$ are found in the Ganges and Indus river basins (India, Pakistan and Bangladesh), in eastern China and in the Mississippi river 
Table 1. Characteristics of ten ethanol providing and seven biodiesel providing crops.

\begin{tabular}{|c|c|c|c|c|c|}
\hline Sugar and starch crops & $\begin{array}{l}\text { Dry mass } \\
\text { fraction } \\
(\%)\end{array}$ & $\begin{array}{l}\text { Fraction of } \\
\text { carbo- } \\
\text { hydrates in } \\
\text { dry mass } \\
\left(\mathrm{g} \mathrm{g}^{-1}\right)\end{array}$ & $\begin{array}{l}\text { Ethanol } \\
\text { per unit } \\
\text { of carbo- } \\
\text { hydrate } \\
\left(\mathrm{g} \mathrm{g}^{-1}\right)\end{array}$ & $\begin{array}{l}\text { Energy } \\
\text { yield* }^{*} \\
\left(\mathrm{GJ} \mathrm{ton}^{-1}\right)\end{array}$ & $\begin{array}{l}\text { Bio- } \\
\text { ethanol } \\
\text { yield** } \\
\left(\text { l ton }^{-1}\right)\end{array}$ \\
\hline Barley & $85 \%$ & 0.76 & 0.53 & 10.2 & 434 \\
\hline Cassava & $38 \%$ & 0.87 & 0.53 & 5.20 & 222 \\
\hline Maize & $85 \%$ & 0.75 & 0.53 & 10.0 & 428 \\
\hline Potatoes & $25 \%$ & 0.78 & 0.53 & 3.07 & 131 \\
\hline Rice, paddy & $85 \%$ & 0.76 & 0.53 & 10.2 & 434 \\
\hline Rye & $85 \%$ & 0.76 & 0.53 & 10.2 & 434 \\
\hline Sorghum & $85 \%$ & 0.76 & 0.53 & 10.2 & 434 \\
\hline Sugar beet & $21 \%$ & 0.82 & 0.51 & 2.61 & 111 \\
\hline Sugar cane & $27 \%$ & 0.57 & 0.51 & 2.33 & 99 \\
\hline Wheat & $85 \%$ & 0.76 & 0.53 & 10.17 & 434 \\
\hline Oil crops & $\begin{array}{l}\text { Dry mass } \\
\text { fraction }(\%)\end{array}$ & $\begin{array}{l}\text { Fraction } \\
\text { of fat in } \\
\text { dry mass } \\
\left(\mathrm{g} \mathrm{g}^{-1}\right)\end{array}$ & $\begin{array}{l}\text { Biodiesel } \\
\text { per unit of } \\
\text { fat }\left(\mathrm{gg}^{-1}\right)\end{array}$ & $\begin{array}{l}\text { Energy } \\
\text { yield* } \\
\left(\mathrm{GJ} \mathrm{ton}^{-1}\right)\end{array}$ & $\begin{array}{l}\text { Biodiesel } \\
\text { yield }^{* *} \\
\left(1 \text { ton }^{-1}\right)\end{array}$ \\
\hline Coconuts & $50 \%$ & 0.03 & 1 & 0.57 & 17 \\
\hline Groundnuts, with shell & $95 \%$ & 0.39 & 1 & 14.0 & 421 \\
\hline Oil palm fruit & $85 \%$ & 0.22 & 1 & 7.05 & 213 \\
\hline Rapeseed & $74 \%$ & 0.42 & 1 & 11.7 & 353 \\
\hline Seed cotton & $85 \%$ & 0.23 & 1 & 7.37 & 222 \\
\hline Soybeans & $92 \%$ & 0.18 & 1 & 6.24 & 188 \\
\hline Sunflower seed & $85 \%$ & 0.22 & 1 & 7.05 & 213 \\
\hline
\end{tabular}

* Based on a higher heating value of $29.7 \mathrm{~kJ} \mathrm{gram}^{-1}$ for ethanol and $37.7 \mathrm{~kJ} \mathrm{gram}^{-1}$ for biodiesel. ** Based on a density of $0.789 \mathrm{~kg}^{-1}$ for ethanol and $0.88 \mathrm{~kg}^{-1}$ for biodiesel (Alptekin and Canakci, 2008).

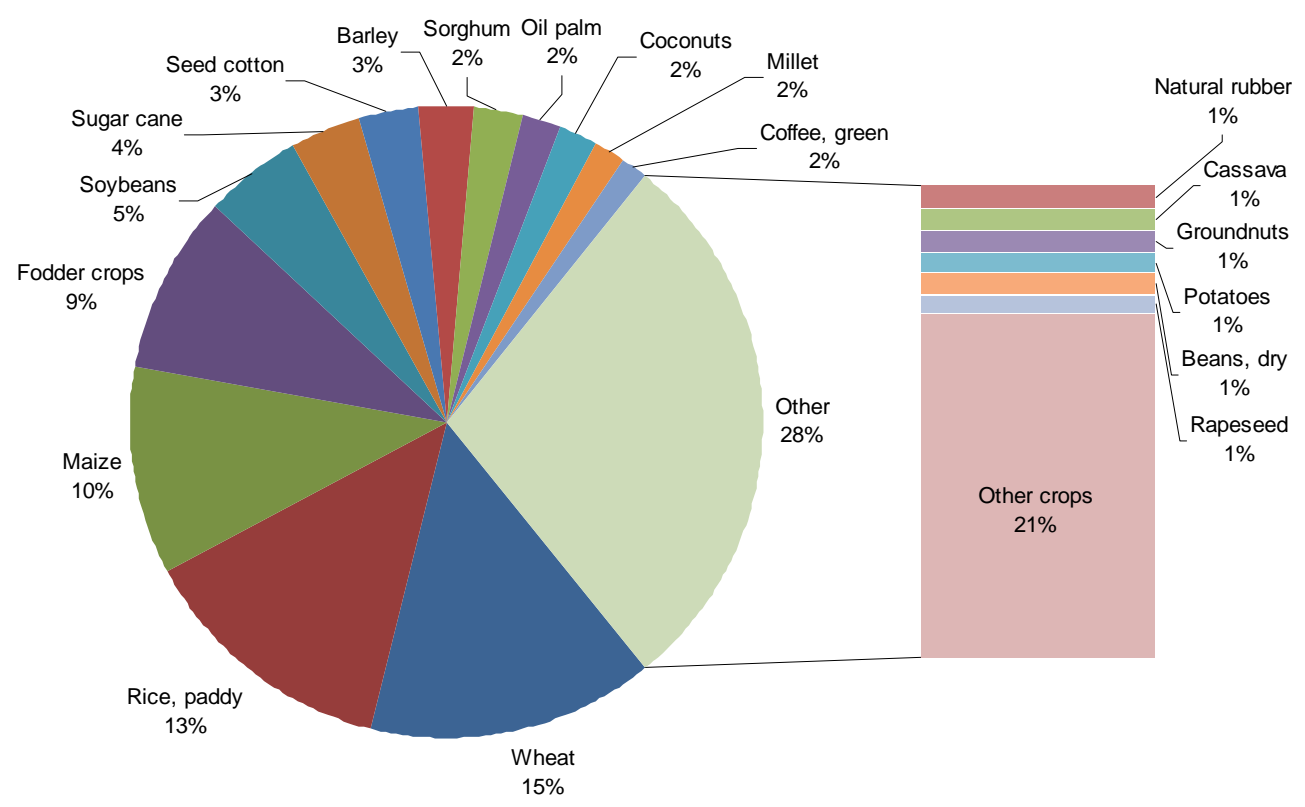

Fig. 1. Contribution of different crops to the total water footprint of crop production. Period: 1996-2005. 


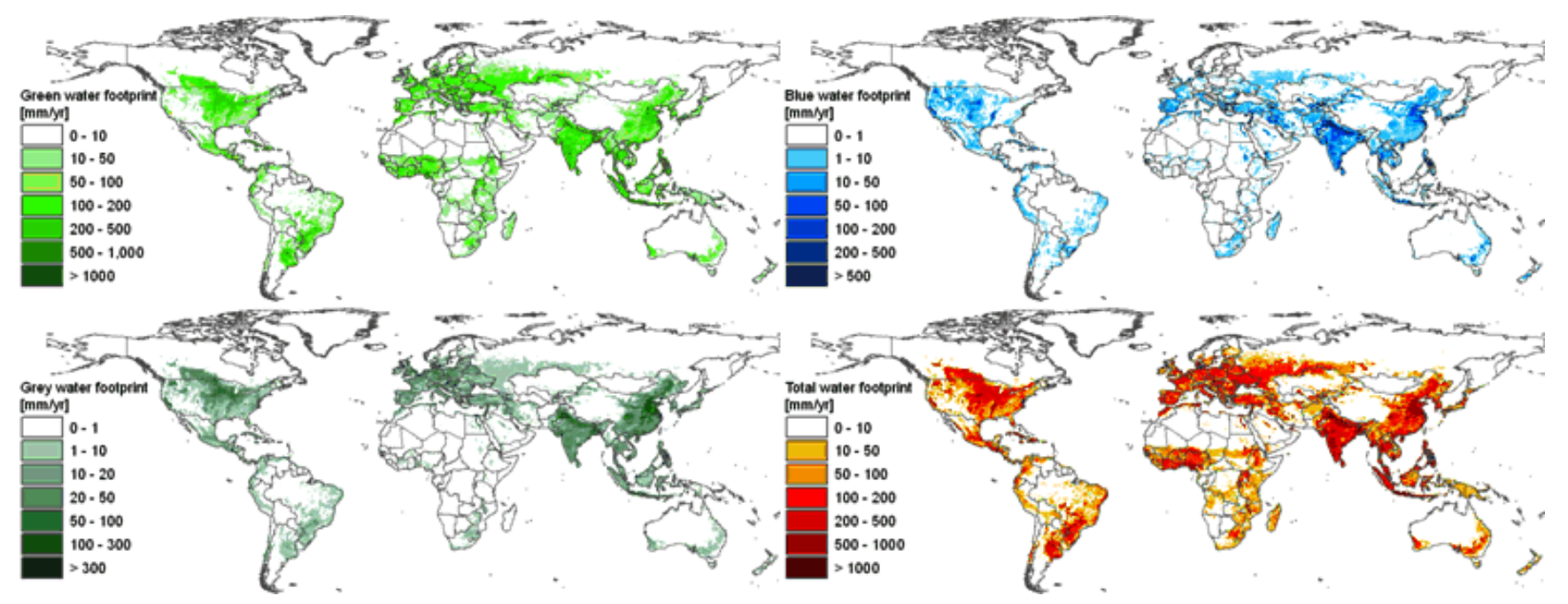

Fig. 2. The green, blue, grey and total water footprint of crop production estimated at a 5 by 5 arc minute resolution. The data are shown in $\mathrm{mm} \mathrm{yr}^{-1}$ and have been calculated as the aggregated water footprint per grid cell (in $\mathrm{m}^{3} \mathrm{yr}^{-1}$ ) divided by the area of the grid cell. Period: 1996-2005.

basin (USA). These locations are the same locations as where the harvested crop area takes a relative large share in the total area (Monfreda et al., 2008).

Globally, $86.5 \%$ of the water consumed in crop production is green water. Even in irrigated agriculture, green water often has a very significant contribution to total water consumption. The share of the blue water footprint in total water consumption (green plus blue water footprint) is shown in Fig. 3. The share of the blue water footprint is largest in arid and semi-arid regions. Regions with a large blue water proportion are located, for example, in the western part of the USA, in a relatively narrow strip of land along the west coast of South America (Peru-Chile), in southern Europe, North Africa, the Arabian peninsula, Central Asia, Pakistan and northern India, northeast China and parts of Australia.

\subsection{The water footprint of primary crops and derived crop products per ton}

The average water footprint per ton of primary crop differs significantly among crops and across production regions. Crops with a high yield or large fraction of crop biomass that is harvested generally have a smaller water footprint per ton than crops with a low yield or small fraction of crop biomass harvested. When considered per ton of product, commodities with relatively large water footprints are: coffee, tea, cocoa, tobacco, spices, nuts, rubber and fibres (Table 2). For food crops, the global average water footprint per ton of crop increases from sugar crops (roughly $200 \mathrm{~m}^{3} \mathrm{ton}^{-1}$ ), vegetables $\left(\sim 300 \mathrm{~m}^{3}\right.$ ton $\left.^{-1}\right)$, roots and tubers $\left(\sim 400 \mathrm{~m}^{3}\right.$ ton $\left.^{-1}\right)$, fruits $\left(\sim 1000 \mathrm{~m}^{3}\right.$ ton $\left.^{-1}\right)$, cereals $\left(\sim 1600 \mathrm{~m}^{3}\right.$ ton $\left.^{-1}\right)$, oil crops $\left(\sim 2400 \mathrm{~m}^{3}\right.$ ton $\left.^{-1}\right)$, pulses $\left(\sim 4000 \mathrm{~m}^{3}\right.$ ton $\left.^{-1}\right)$, spices $\left(\sim 7000 \mathrm{~m}^{3}\right.$ ton $\left.^{-1}\right)$ to nuts $\left(\sim 9000 \mathrm{~m}^{3}\right.$ ton $\left.^{-1}\right)$. The water footprint varies, however, across different crops per crop category. Besides, if one considers the water footprint per kcal, the picture changes as well. Vegetables and fruits, which have a relatively small water footprint per $\mathrm{kg}$ but a low caloric content, have a relatively large water footprint per kcal.

Global average water footprints of selected primary crops and their derived products are presented in Table 3 . The results allow us to compare the water footprints of different products:

- The average water footprint for cereal crops is $1644 \mathrm{~m}^{3}$ ton $^{-1}$, but the footprint for wheat is relatively large $\left(1827 \mathrm{~m}^{3}\right.$ ton $\left.^{-1}\right)$, while for maize it is relatively small $\left(1222 \mathrm{~m}^{3}\right.$ ton $\left.^{-1}\right)$. The average water footprint of rice is close to the average for all cereals together.

- Sugar obtained from sugar beet has a smaller water footprint than sugar from sugar cane. Besides, the blue component in the total water footprint of beet sugar $(20 \%)$ is smaller than for cane sugar $(27 \%)$.

- For vegetable oils we find a large variation in water footprints: maize oil $2600 \mathrm{~m}^{3}$ ton $^{-1}$; cotton-seed oil $3800 \mathrm{~m}^{3}$ ton $^{-1}$; soybean oil $4200 \mathrm{~m}^{3}$ ton $^{-1}$; rapeseed oil $4300 \mathrm{~m}^{3}$ ton $^{-1}$; palm oil $5000 \mathrm{~m}^{3}$ ton $^{-1}$; sunflower oil $6800 \mathrm{~m}^{3}$ ton $^{-1}$; groundnut oil $7500 \mathrm{~m}^{3}$ ton $^{-1}$; linseed oil $9400 \mathrm{~m}^{3}$ ton $^{-1}$; olive oil $14500 \mathrm{~m}^{3}$ ton $^{-1}$; castor oil $24700 \mathrm{~m}^{3}$ ton $^{-1}$.

- For fruits we find a similar variation in water footprints: watermelon $235 \mathrm{~m}^{3}$ ton $^{-1}$; pineapple $255 \mathrm{~m}^{3}$ ton $^{-1}$; papaya $460 \mathrm{~m}^{3}$ ton $^{-1}$; orange $560 \mathrm{~m}^{3}$ ton $^{-1}$; banana $790 \mathrm{~m}^{3}$ ton $^{-1}$; apple $820 \mathrm{~m}^{3}$ ton $^{-1}$; peach $910 \mathrm{~m}^{3}$ ton $^{-1}$; pear $920 \mathrm{~m}^{3}$ ton $^{-1}$; apricot $1300 \mathrm{~m}^{3}$ ton $^{-1}$; plums 2200 


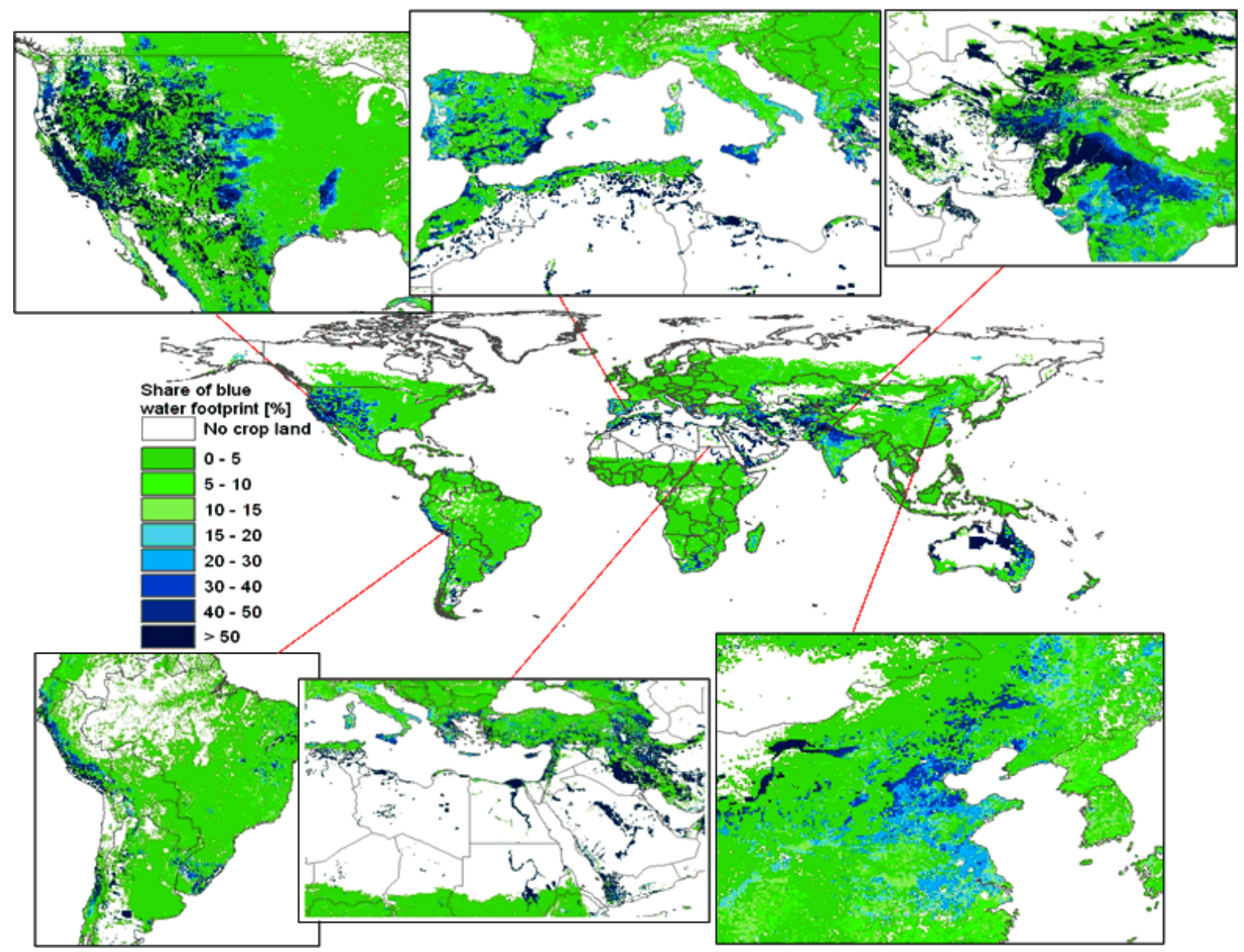

Fig. 3. Contribution of the blue water footprint to the total consumptive (green and blue) water footprint of crop production. Period: 19962005.

$\mathrm{m}^{3}$ ton $^{-1}$; dates $2300 \mathrm{~m}^{3}$ ton $^{-1}$; grapes $2400 \mathrm{~m}^{3}$ ton $^{-1}$; figs $3350 \mathrm{~m}^{3}$ ton $^{-1}$.

- For alcoholic beverages we find: a water footprint of $300 \mathrm{~m}^{3}$ ton $^{-1}$ for beer and $870 \mathrm{~m}^{3}$ ton $^{-1}$ for wine.

- The water footprints of juices vary from tomato juice $\left(270 \mathrm{~m}^{3}\right.$ ton $\left.^{-1}\right)$, grapefruit juice $\left(675 \mathrm{~m}^{3}\right.$ ton $\left.^{-1}\right)$, orange juice $\left(1000 \mathrm{~m}^{3}\right.$ ton $\left.^{-1}\right)$ and apple juice $\left(1100 \mathrm{~m}^{3}\right.$ ton $\left.^{-1}\right)$ to pineapple juice $\left(1300 \mathrm{~m}^{3}\right.$ ton $\left.^{-1}\right)$.

- The water footprint of coffee (1301 cup ${ }^{-1}$, based on use of 7 gram of roasted coffee per cup) is much larger than the water footprint of tea $\left(271 \mathrm{cup}^{-1}\right.$, based on use of 3 gram of black tea per cup).

- The water footprint of cotton fibres is substantially larger than the water footprints of sisal and flax fibres, which are again larger than the water footprints of jute and hemp fibres.

One should be careful in drawing conclusions from the above product comparisons. Although the global average water footprint of one product may be larger than the global average water footprint of another product, the comparison may turn out quite differently for specific regions.

The water footprints of crops vary across countries and regions as well. This is mainly due to differences in crop yields, as shown in Table 4 for the case of cereal crops. Relatively small water footprints per ton of cereal crops were calculated for Northern Europe $\left(637 \mathrm{~m}^{3}\right.$ ton $\left.^{-1}\right)$ and Western Europe $\left(654 \mathrm{~m}^{3}\right.$ ton $\left.^{-1}\right)$. On the other hand, with the exception of Southern Africa, the water footprints of cereal crops are quite large in most parts of Africa. While the average crop water requirement in Europe was only $11 \%$ lower to that observed in Africa, the average water footprint of cereal crops in Europe was about three times smaller than in Africa, which can mainly be explained by the higher average yield in Europe (3.4 ton ha ${ }^{-1}$ ) compared to that observed in Africa $\left(1.3\right.$ ton ha $\left.{ }^{-1}\right)$. A similar observation can be made for other regions as well: while crop water requirements in America, on average, are higher than in Asia, due to a higher yield, the average water footprint of cereals in America is smaller compared to the value calculated for Asia. Figure 4 
Table 2. .Global average water footprint of 14 primary crop categories. Period: 1996-2005.

\begin{tabular}{|c|c|c|c|c|c|c|}
\hline \multirow[t]{2}{*}{ Primary crop category } & \multicolumn{4}{|c|}{$\begin{array}{l}\text { Water footprint } \\
\left(\mathrm{m}^{3} \text { ton }^{-1}\right)\end{array}$} & \multirow{2}{*}{$\begin{array}{r}\text { Caloric value* } \\
\quad\left(\mathrm{kcal} \mathrm{kg}^{-1}\right)\end{array}$} & \multirow{2}{*}{$\begin{array}{l}\text { Water footprint } \\
\qquad\left(1 \mathrm{kcal}^{-1}\right)\end{array}$} \\
\hline & Green & Blue & Grey & Total & & \\
\hline Sugar crops & 130 & 52 & 15 & 197 & 290 & 0.68 \\
\hline Fodder crops & 207 & 27 & 20 & 253 & - & - \\
\hline Vegetables & 194 & 43 & 85 & 322 & 240 & 1.34 \\
\hline Roots and tubers & 327 & 16 & 43 & 387 & 830 & 0.47 \\
\hline Fruits & 727 & 147 & 93 & 967 & 460 & 2.10 \\
\hline Cereals & 1232 & 228 & 184 & 1644 & 3200 & 0.51 \\
\hline Oil crops & 2023 & 220 & 121 & 2364 & 2900 & 0.81 \\
\hline Tobacco & 2021 & 205 & 700 & 2925 & - & - \\
\hline Fibres, vegetal origin & 3375 & 163 & 300 & 3837 & - & - \\
\hline Pulses & 3180 & 141 & 734 & 4055 & 3400 & 1.19 \\
\hline Spices & 5872 & 744 & 432 & 7048 & 3000 & 2.35 \\
\hline Nuts & 7016 & 1367 & 680 & 9063 & 2500 & 3.63 \\
\hline Rubber, gums, waxes & 12964 & 361 & 422 & 13748 & - & - \\
\hline Stimulants & 13731 & 252 & 460 & 14443 & 880 & 16.4 \\
\hline
\end{tabular}

* Source: FAO (2008a).

shows the relationship between cereal yield and water footprint, where the dots represent country averages. From the figure we can observe a general trend between the water footprint and yield of cereals which follows a logarithmic function. This suggests that the water footprint of a crop, to a large extent, is influenced by agricultural management rather than by the agro-climate under which the crop is grown and that cannot be influenced by the farmer. This provides an opportunity to improve water productivity, i.e., to produce more food per unit of water consumption. According to Rockström et al. (2003), this opportunity is particularly large in the range of low crop yields, due to the current large losses in non-productive green water evaporation.

\subsection{The water footprint of biofuels per GJ and per litre}

The water footprint of biofuel varies across both crops and countries. The variation is due to differences in crop yields across countries and crops, differences in energy yields across crops and differences in climate and agricultural practices across countries. Table 5 shows the global average water footprint of biofuel for a number of crops providing ethanol and some other crops providing biodiesel. Among the crops providing ethanol, sorghum has the largest water footprint, with 70001 of water per litre of ethanol, which is equivalent to $300 \mathrm{~m}^{3} \mathrm{GJ}^{-1}$. Bio-ethanol based on sugar beet has the smallest global average water footprint, with 12001 of water per litre of ethanol, equivalent to $50 \mathrm{~m}^{3} \mathrm{GJ}^{-1}$. In general, biodiesel has a larger water footprint per unit of energy obtained than bio-ethanol, a finding that is consistent with Gerbens-Leenes et al. (2009). Among the crops studied here, biodiesel from coconuts has the largest water foot- print: $4750 \mathrm{~m}^{3} \mathrm{GJ}^{-1}$. Biodiesels from oil palm, rapeseed and groundnuts are more efficient, with water footprints in the range $150-200 \mathrm{~m}^{3} \mathrm{GJ}^{-1}$. The largest blue water footprint is observed for biodiesel from cotton: $177 \mathrm{~m}^{3} \mathrm{GJ}^{-1}$ (32\% of the total water footprint).

\subsection{The total water footprint of crop production at national and sub-national level}

At the country level, the largest total water footprints were estimated for India, China, the USA, Brazil, Russia and Indonesia. These six countries together account for about half of the global total water footprint related to crop production. The largest green water footprints are also found in these six countries: India, China, the USA, Russia, Brazil and Indonesia. Data per country are shown in Table 6 for the largest producers. At sub-national level (state or province level), the largest green water footprints can be found in Uttar Pradesh $\left(88 \mathrm{Gm}^{3} \mathrm{yr}^{-1}\right)$, Maharashtra $\left(86 \mathrm{Gm}^{3} \mathrm{yr}^{-1}\right)$, Karnataka $\left(65 \mathrm{Gm}^{3} \mathrm{yr}^{-1}\right)$, Andhra Pradesh $\left(61 \mathrm{Gm}^{3} \mathrm{yr}^{-1}\right)$, and Madhya Pradesh $\left(60 \mathrm{Gm}^{3} \mathrm{yr}^{-1}\right)$, all in India. The largest blue water footprints were calculated for India, China, the USA and Pakistan. These four countries together account for $58 \%$ of the total blue water footprint related to crop production. At sub-national level, the largest blue water footprints were found in: Uttar Pradesh $\left(59 \mathrm{Gm}^{3} \mathrm{yr}^{-1}\right)$ and Madhya Pradesh $\left(24 \mathrm{Gm}^{3} \mathrm{yr}^{-1}\right)$ in India; Punjab $\left(50 \mathrm{Gm}^{3} \mathrm{yr}^{-1}\right)$ in Pakistan; and California $\left(20 \mathrm{Gm}^{3} \mathrm{yr}^{-1}\right)$ in the USA. Large grey water footprints were estimated for China, the USA and India. 
Table 3. Global average water footprint of primary crops and derived crop products. Period: 1996-2005.

\begin{tabular}{|c|c|c|c|c|c|}
\hline \multirow[t]{2}{*}{$\begin{array}{l}\text { FAOSTAT } \\
\text { crop code }\end{array}$} & \multirow[t]{2}{*}{ Product description } & \multicolumn{4}{|c|}{$\begin{array}{l}\text { Global average water } \\
\text { footprint }\left(\mathrm{m}^{3} \text { ton }^{-1}\right)\end{array}$} \\
\hline & & Green & Blue & Grey & Total \\
\hline \multirow[t]{7}{*}{15} & Wheat & 1277 & 342 & 207 & 1827 \\
\hline & Wheat flour & 1292 & 347 & 210 & 1849 \\
\hline & Wheat bread & 1124 & 301 & 183 & 1608 \\
\hline & Dry pasta & 1292 & 347 & 210 & 1849 \\
\hline & Wheat pellets & 1423 & 382 & 231 & 2036 \\
\hline & Wheat, starch & 1004 & 269 & 163 & 1436 \\
\hline & Wheat gluten & 2928 & 785 & 476 & 4189 \\
\hline \multirow[t]{5}{*}{27} & Rice, paddy & 1146 & 341 & 187 & 1673 \\
\hline & Rice, husked (brown) & 1488 & 443 & 242 & 2172 \\
\hline & Rice, broken & 1710 & 509 & 278 & 2497 \\
\hline & Rice flour & 1800 & 535 & 293 & 2628 \\
\hline & Rice groats and meal & 1527 & 454 & 249 & 2230 \\
\hline \multirow[t]{5}{*}{44} & Barley & 1213 & 79 & 131 & 1423 \\
\hline & Barley, rolled or flaked grains & 1685 & 110 & 182 & 1977 \\
\hline & Malt, not roasted & 1662 & 108 & 180 & 1950 \\
\hline & Malt, roasted & 2078 & 135 & 225 & 2437 \\
\hline & Beer made from malt & 254 & 16 & 27 & 298 \\
\hline \multirow[t]{6}{*}{56} & Maize (corn) & 947 & 81 & 194 & 1222 \\
\hline & Maize (corn) flour & 971 & 83 & 199 & 1253 \\
\hline & Maize (corn) groats and meal & 837 & 72 & 171 & 1081 \\
\hline & Maize (corn), hulled, pearled, sliced or kibbled & 1018 & 87 & 209 & 1314 \\
\hline & Maize (corn) starch & 1295 & 111 & 265 & 1671 \\
\hline & Maize (corn) oil & 1996 & 171 & 409 & 2575 \\
\hline \multirow[t]{2}{*}{71} & Rye & 1419 & 25 & 99 & 1544 \\
\hline & Rye flour & 1774 & 32 & 124 & 1930 \\
\hline \multirow[t]{3}{*}{75} & Oats & 1479 & 181 & 128 & 1788 \\
\hline & Oat groats and meal & 2098 & 257 & 182 & 2536 \\
\hline & Oats, rolled or flaked grains & 1998 & 245 & 173 & 2416 \\
\hline 79 & Millet & 4306 & 57 & 115 & 4478 \\
\hline 83 & Sorghum & 2857 & 103 & 87 & 3048 \\
\hline 89 & Buckwheat & 2769 & 144 & 229 & 3142 \\
\hline \multirow[t]{5}{*}{116} & Potatoes & 191 & 33 & 63 & 287 \\
\hline & Tapioca of potatoes & 955 & 165 & 317 & 1436 \\
\hline & Potato flour and meal & 955 & 165 & 317 & 1436 \\
\hline & Potato flakes & 694 & 120 & 230 & 1044 \\
\hline & Potato starch & 1005 & 173 & 333 & 1512 \\
\hline 122 & Sweet potatoes & 324 & 5 & 53 & 383 \\
\hline \multirow[t]{5}{*}{125} & Manioc (cassava) & 550 & 0 & 13 & 564 \\
\hline & Tapioca of cassava & 2750 & 1 & 66 & 2818 \\
\hline & Flour of cassava & 1833 & 1 & 44 & 1878 \\
\hline & Dried cassava & 1571 & 1 & 38 & 1610 \\
\hline & Manioc (cassava) starch & 2200 & 1 & 53 & 2254 \\
\hline 136 & Taro (coco yam) & 587 & 3 & 15 & 606 \\
\hline 137 & Yams & 341 & 0 & 1 & 343 \\
\hline
\end{tabular}


Table 3. Continued.

\begin{tabular}{|c|c|c|c|c|c|}
\hline \multirow[t]{2}{*}{$\begin{array}{l}\text { FAOSTAT } \\
\text { crop code }\end{array}$} & \multirow[t]{2}{*}{ Product description } & \multicolumn{4}{|c|}{$\begin{array}{l}\text { Global average water } \\
\text { footprint }\left(\mathrm{m}^{3} \text { ton }^{-1}\right)\end{array}$} \\
\hline & & Green & Blue & Grey & Total \\
\hline \multirow[t]{5}{*}{156} & Sugar cane & 139 & 57 & 13 & 210 \\
\hline & Raw sugar, cane & 1107 & 455 & 104 & 1666 \\
\hline & Refined sugar & 1184 & 487 & 111 & 1782 \\
\hline & Fructose, chemically pure & 1184 & 487 & 111 & 1782 \\
\hline & Cane molasses & 350 & 144 & 33 & 527 \\
\hline \multirow[t]{2}{*}{157} & Sugar beet & 82 & 26 & 25 & 132 \\
\hline & Raw sugar, beet & 535 & 167 & 162 & 865 \\
\hline 176 & Beans, dry & 3945 & 125 & 983 & 5053 \\
\hline 181 & Broad beans, horse beans, dry & 1317 & 205 & 496 & 2018 \\
\hline 187 & Peas, dry & 1453 & 33 & 493 & 1979 \\
\hline 191 & Chick peas & 2972 & 224 & 981 & 4177 \\
\hline 195 & Cow peas, dry & 6841 & 10 & 55 & 6906 \\
\hline 197 & Pigeon peas & 4739 & 72 & 683 & 5494 \\
\hline 201 & Lentils & 4324 & 489 & 1060 & 5874 \\
\hline 217 & Cashew nuts & 12853 & 921 & 444 & 14218 \\
\hline 220 & Chestnuts & 2432 & 174 & 144 & 2750 \\
\hline \multirow[t]{2}{*}{221} & Almonds, with shell & 4632 & 1908 & 1507 & 8047 \\
\hline & Almonds, shelled or peeled & 9264 & 3816 & 3015 & 16095 \\
\hline \multirow[t]{2}{*}{222} & Walnuts, with shell & 2805 & 1299 & 814 & 4918 \\
\hline & Walnuts, shelled or peeled & 5293 & 2451 & 1536 & 9280 \\
\hline 223 & Pistachios & 3095 & 7602 & 666 & 11363 \\
\hline 224 & Kola nuts & 23345 & 26 & 19 & 23391 \\
\hline \multirow[t]{2}{*}{225} & Hazelnuts, with shell & 3813 & 1090 & 354 & 5258 \\
\hline & Hazelnuts, shelled or peeled & 7627 & 2180 & 709 & 10515 \\
\hline 226 & Areca nuts & 10621 & 139 & 406 & 11165 \\
\hline \multirow[t]{8}{*}{236} & Soya beans & 2037 & 70 & 37 & 2145 \\
\hline & Soya sauce & 582 & 20 & 11 & 613 \\
\hline & Soya paste & 543 & 19 & 10 & 572 \\
\hline & Soya curd & 2397 & 83 & 44 & 2523 \\
\hline & Soy milk & 3574 & 123 & 65 & 3763 \\
\hline & Soya bean flour and meals & 2397 & 83 & 44 & 2523 \\
\hline & Soybean oil, refined & 3980 & 137 & 73 & 4190 \\
\hline & Soybean oilcake & 1690 & 58 & 31 & 1779 \\
\hline \multirow[t]{4}{*}{242} & Groundnuts in shell & 2469 & 150 & 163 & 2782 \\
\hline & Groundnuts shelled & 3526 & 214 & 234 & 3974 \\
\hline & Groundnut oil, refined & 6681 & 405 & 442 & 7529 \\
\hline & Groundnut oilcake & 1317 & 80 & 87 & 1484 \\
\hline
\end{tabular}


Table 3. Continued.

\begin{tabular}{|c|c|c|c|c|c|}
\hline \multirow[t]{2}{*}{$\begin{array}{l}\text { FAOSTAT } \\
\text { crop code }\end{array}$} & \multirow[t]{2}{*}{ Product description } & \multicolumn{4}{|c|}{$\begin{array}{l}\text { Global average water } \\
\text { footprint }\left(\mathrm{m}^{3} \text { ton }^{-1}\right)\end{array}$} \\
\hline & & Green & Blue & Grey & Total \\
\hline \multirow[t]{6}{*}{249} & Coconuts & 2669 & 2 & 16 & 2687 \\
\hline & Copra & 2079 & 1 & 12 & 2093 \\
\hline & Coconut (husked) & 1247 & 1 & 7 & 1256 \\
\hline & Coconut (copra) oil, refined & 4461 & 3 & 27 & 4490 \\
\hline & Coconut/copra oilcake & 829 & 1 & 5 & 834 \\
\hline & Coconut (coir) fibre, processed & 2433 & 2 & 15 & 2449 \\
\hline \multirow[t]{5}{*}{254} & Oil palm & 1057 & 0 & 40 & 1098 \\
\hline & Palm nuts and kernels & 2762 & 1 & 105 & 2868 \\
\hline & Palm oil, refined & 4787 & 1 & 182 & 4971 \\
\hline & Palm kernel/babassu oil, refined & 5202 & 1 & 198 & 5401 \\
\hline & Palm nut/kernel oilcake & 802 & 0 & 31 & 833 \\
\hline \multirow[t]{3}{*}{260} & Olives & 2470 & 499 & 45 & 3015 \\
\hline & Olive oil, virgin & 11826 & 2388 & 217 & 14431 \\
\hline & Olive oil, refined & 12067 & 2437 & 221 & 14726 \\
\hline \multirow[t]{2}{*}{265} & Castor oil seeds & 8423 & 1175 & 298 & 9896 \\
\hline & Castor oil & 21058 & 2938 & 744 & 24740 \\
\hline \multirow[t]{3}{*}{267} & Sunflower seeds & 3017 & 148 & 201 & 3366 \\
\hline & Sunflower seed oil, refined & 6088 & 299 & 405 & 6792 \\
\hline & Sunflower seed oilcake & 1215 & 60 & 81 & 1356 \\
\hline \multirow[t]{3}{*}{270} & Rapeseed & 1703 & 231 & 336 & 2271 \\
\hline & Rape oil, refined & 3226 & 438 & 636 & 4301 \\
\hline & Rape seed oilcake & 837 & 114 & 165 & 1115 \\
\hline 280 & Safflower seeds & 6000 & 938 & 283 & 7221 \\
\hline \multirow[t]{2}{*}{289} & Sesame seed & 8460 & 509 & 403 & 9371 \\
\hline & Sesame oil & 19674 & 1183 & 936 & 21793 \\
\hline 292 & Mustard seeds & 2463 & 1 & 345 & 2809 \\
\hline 296 & Poppy seeds & 1723 & 0 & 464 & 2188 \\
\hline 299 & Melon seed & 5087 & 56 & 41 & 5184 \\
\hline \multirow[t]{11}{*}{328} & Seed cotton & 2282 & 1306 & 440 & 4029 \\
\hline & Cotton seeds & 755 & 432 & 146 & 1332 \\
\hline & Cotton lint & 5163 & 2955 & 996 & 9113 \\
\hline & Cotton linters & 1474 & 844 & 284 & 2602 \\
\hline & Cotton-seed oil, refined & 2242 & 1283 & 432 & 3957 \\
\hline & Cotton seed oilcake & 487 & 279 & 94 & 860 \\
\hline & Cotton, not carded or combed & 5163 & 2955 & 996 & 9113 \\
\hline & Cotton yarn waste (including thread waste) & 950 & 544 & 183 & 1677 \\
\hline & Garneted stock of cotton & 1426 & 816 & 275 & 2517 \\
\hline & Cotton, carded or combed & 5359 & 3067 & 1034 & 9460 \\
\hline & Cotton fabric, finished textile & 5384 & 3253 & 1344 & 9982 \\
\hline \multirow[t]{3}{*}{333} & Linseed & 4730 & 268 & 170 & 5168 \\
\hline & Linseed oil, refined & 8618 & 488 & 310 & 9415 \\
\hline & Linseed oilcake & 2816 & 160 & 101 & 3077 \\
\hline 336 & Hempseed & 3257 & 12 & 417 & 3685 \\
\hline 358 & Cabbages and other brassicas & 181 & 26 & 73 & 280 \\
\hline
\end{tabular}


Table 3. Continued.

\begin{tabular}{|c|c|c|c|c|c|}
\hline \multirow[t]{2}{*}{$\begin{array}{l}\text { FAOSTAT } \\
\text { crop code }\end{array}$} & \multirow[t]{2}{*}{ Product description } & \multicolumn{4}{|c|}{$\begin{array}{l}\text { Global average water } \\
\text { footprint }\left(\mathrm{m}^{3} \operatorname{ton}^{-1}\right)\end{array}$} \\
\hline & & Green & Blue & Grey & Total \\
\hline 366 & Artichokes & 478 & 242 & 98 & 818 \\
\hline 367 & Asparagus & 1524 & 119 & 507 & 2150 \\
\hline 372 & Lettuce & 133 & 28 & 77 & 237 \\
\hline 373 & Spinach & 118 & 14 & 160 & 292 \\
\hline \multirow[t]{8}{*}{388} & Tomatoes & 108 & 63 & 43 & 214 \\
\hline & Tomato juice unfermented \& not spirited & 135 & 79 & 53 & 267 \\
\hline & Tomato juice, concentrated & 539 & 316 & 213 & 1069 \\
\hline & Tomato paste & 431 & 253 & 171 & 855 \\
\hline & Tomato ketchup & 270 & 158 & 107 & 534 \\
\hline & Tomato puree & 360 & 211 & 142 & 713 \\
\hline & Peeled tomatoes & 135 & 79 & 53 & 267 \\
\hline & Tomato, dried & 2157 & 1265 & 853 & 4276 \\
\hline \multirow[t]{2}{*}{393} & Cauliflowers and broccoli & 189 & 21 & 75 & 285 \\
\hline & Brussels sprouts & 189 & 21 & 75 & 285 \\
\hline 394 & Pumpkins, squash and gourds & 228 & 24 & 84 & 336 \\
\hline 397 & Cucumbers and gherkins & 206 & 42 & 105 & 353 \\
\hline 399 & Eggplants (aubergines) & 234 & 33 & 95 & 362 \\
\hline 401 & Chillies and peppers, green & 240 & 42 & 97 & 379 \\
\hline 402 & Onions (incl. shallots), green & 176 & 44 & 51 & 272 \\
\hline 403 & Onions, dry & 192 & 88 & 65 & 345 \\
\hline \multirow[t]{2}{*}{406} & Garlic & 337 & 81 & 170 & 589 \\
\hline & Garlic powder & 1297 & 313 & 655 & 2265 \\
\hline 414 & Beans, green & 320 & 54 & 188 & 561 \\
\hline 417 & Peas, green & 382 & 63 & 150 & 595 \\
\hline 423 & String beans & 301 & 104 & 143 & 547 \\
\hline 426 & Carrots and turnips & 106 & 28 & 61 & 195 \\
\hline 430 & Okra & 474 & 36 & 65 & 576 \\
\hline 446 & Maize, green & 455 & 157 & 88 & 700 \\
\hline 461 & Carobs & 4557 & 334 & 703 & 5594 \\
\hline 486 & Bananas & 660 & 97 & 33 & 790 \\
\hline 489 & Plantains & 1570 & 27 & 6 & 1602 \\
\hline \multirow[t]{2}{*}{490} & Oranges & 401 & 110 & 49 & 560 \\
\hline & Orange juice & 729 & 199 & 90 & 1018 \\
\hline 495 & Tangerines, mandarins, clement & 479 & 118 & 152 & 748 \\
\hline 497 & Lemons and limes & 432 & 152 & 58 & 642 \\
\hline 507 & Grapefruit & 367 & 85 & 54 & 506 \\
\hline
\end{tabular}


Table 3. Continued.

\begin{tabular}{|c|c|c|c|c|c|}
\hline \multirow[t]{2}{*}{$\begin{array}{l}\text { FAOSTAT } \\
\text { crop code }\end{array}$} & \multirow[t]{2}{*}{ Product description } & \multicolumn{4}{|c|}{$\begin{array}{l}\text { Global average water } \\
\text { footprint }\left(\mathrm{m}^{3} \text { ton }^{-1}\right)\end{array}$} \\
\hline & & Green & Blue & Grey & Total \\
\hline \multirow[t]{3}{*}{515} & Apples, fresh & 561 & 133 & 127 & 822 \\
\hline & Apples, dried & 4678 & 1111 & 1058 & 6847 \\
\hline & Apple juice unfermented \& not spirited & 780 & 185 & 176 & 1141 \\
\hline 521 & Pears & 645 & 94 & 183 & 922 \\
\hline 526 & Apricots & 694 & 502 & 92 & 1287 \\
\hline 530 & Sour cherries & 1098 & 213 & 99 & 1411 \\
\hline 531 & Cherries & 961 & 531 & 112 & 1604 \\
\hline 534 & Peaches and nectarines & 583 & 188 & 139 & 910 \\
\hline 536 & Plums and sloes & 1570 & 188 & 422 & 2180 \\
\hline 544 & Strawberries & 201 & 109 & 37 & 347 \\
\hline 547 & Raspberries & 293 & 53 & 67 & 413 \\
\hline 549 & Gooseberries & 487 & 8 & 31 & 526 \\
\hline 550 & Currants & 457 & 19 & 23 & 499 \\
\hline 552 & Blueberries & 341 & 334 & 170 & 845 \\
\hline 554 & Cranberries & 91 & 108 & 77 & 276 \\
\hline \multirow[t]{4}{*}{560} & Grapes & 425 & 97 & 87 & 608 \\
\hline & Grapes, dried & 1700 & 386 & 347 & 2433 \\
\hline & Grapefruit juice & 490 & 114 & 71 & 675 \\
\hline & Grape wines, sparkling & 607 & 138 & 124 & 869 \\
\hline 567 & Watermelons & 147 & 25 & 63 & 235 \\
\hline 569 & Figs & 1527 & 1595 & 228 & 3350 \\
\hline 571 & Mangoes, mangosteens, guavas & 1314 & 362 & 124 & 1800 \\
\hline 572 & Avocados & 849 & 283 & 849 & 1981 \\
\hline \multirow[t]{2}{*}{574} & Pineapples & 215 & 9 & 31 & 255 \\
\hline & Pineapple juice & 1075 & 45 & 153 & 1273 \\
\hline 577 & Dates & 930 & 1250 & 98 & 2277 \\
\hline 591 & Cashew apple & 3638 & 34 & 121 & 3793 \\
\hline 592 & Kiwi fruit & 307 & 168 & 38 & 514 \\
\hline 600 & Papayas & 399 & 40 & 21 & 460 \\
\hline \multirow[t]{2}{*}{656} & Coffee, green & 15249 & 116 & 532 & 15897 \\
\hline & Coffee, roasted & 18153 & 139 & 633 & 18925 \\
\hline \multirow[t]{5}{*}{661} & Cocoa beans & 19745 & 4 & 179 & 19928 \\
\hline & Cocoa paste & 24015 & 5 & 218 & 24238 \\
\hline & Cocoa butter, fat and oil & 33626 & 7 & 305 & 33938 \\
\hline & Cocoa powder & 15492 & 3 & 141 & 15636 \\
\hline & Chocolate & 16805 & 198 & 193 & 17196 \\
\hline 667 & Green and black tea & 7232 & 898 & 726 & 8856 \\
\hline
\end{tabular}


Table 3. Continued.

\begin{tabular}{|c|c|c|c|c|c|}
\hline \multirow[t]{2}{*}{$\begin{array}{l}\text { FAOSTAT } \\
\text { crop code }\end{array}$} & \multirow[t]{2}{*}{ Product description } & \multicolumn{4}{|c|}{$\begin{array}{l}\text { Global average water } \\
\text { footprint }\left(\mathrm{m}^{3} \text { ton }^{-1}\right)\end{array}$} \\
\hline & & Green & Blue & Grey & Total \\
\hline \multirow[t]{2}{*}{677} & Hop cones & 2382 & 269 & 1414 & 4065 \\
\hline & Hop extract & 9528 & 1077 & 5654 & 16259 \\
\hline 687 & Pepper of the genus Piper & 6540 & 467 & 604 & 7611 \\
\hline 689 & Chillies and peppers, dry & 5869 & 1125 & 371 & 7365 \\
\hline 692 & Vanilla beans & 86392 & 39048 & 1065 & 126505 \\
\hline 693 & Cinnamon (canella) & 14853 & 41 & 632 & 15526 \\
\hline 698 & Cloves & 59834 & 30 & 1341 & 61205 \\
\hline 702 & Nutmeg, mace and cardamoms & 30683 & 2623 & 1014 & 34319 \\
\hline \multirow[t]{2}{*}{711} & Anise, badian, fennel, coriander & 5369 & 1865 & 1046 & 8280 \\
\hline & Coriander seeds & 5369 & 1865 & 1046 & 8280 \\
\hline 720 & Ginger & 1525 & 40 & 92 & 1657 \\
\hline 748 & Peppermint & 206 & 63 & 19 & 288 \\
\hline \multirow[t]{3}{*}{773} & Flax fibre and tow & 2637 & 443 & 401 & 3481 \\
\hline & Flax fibre, otherwise processed but not spun & 2866 & 481 & 436 & 3783 \\
\hline & Flax tow and waste & 581 & 98 & 88 & 767 \\
\hline \multirow[t]{2}{*}{777} & Hemp fibre and tow & 1824 & - & 624 & 2447 \\
\hline & True hemp fibre processed but not spun & 2026 & - & 693 & 2719 \\
\hline 780 & Jute and other textile bast fibres & 2356 & 33 & 217 & 2605 \\
\hline 788 & Ramie & 3712 & 201 & 595 & 4507 \\
\hline \multirow[t]{2}{*}{789} & Sisal & 6112 & 708 & 222 & 7041 \\
\hline & Sisal textile fibres processed but not spun & 6791 & 787 & 246 & 7824 \\
\hline 800 & Agave fibres & 6434 & 9 & 106 & 6549 \\
\hline \multirow[t]{2}{*}{809} & Manila fibre (Abaca) & 19376 & 246 & 766 & 20388 \\
\hline & Abaca fibre, processed but not spun & 21529 & 273 & 851 & 22654 \\
\hline 826 & Tobacco, unmanufactured & 2021 & 205 & 700 & 2925 \\
\hline 836 & Natural rubber & 12964 & 361 & 422 & 13748 \\
\hline
\end{tabular}

\subsection{The total water footprint of crop production at river basin level}

At the river basin level, large water footprints were calculated for the Mississippi, Ganges, Yangtze, Indus and Parana river basins (Table 7). These five river basins together account for $23 \%$ of the global water footprint related to crop production. The largest green water footprint was calculated for the Mississippi river basin $\left(424 \mathrm{Gm}^{3} \mathrm{yr}^{-1}\right)$. The largest blue water footprints were found in the basins of the Indus $\left(117 \mathrm{Gm}^{3} \mathrm{yr}^{-1}\right)$ and Ganges $\left(108 \mathrm{Gm}^{3} \mathrm{yr}^{-1}\right)$. These two river basins together account for $25 \%$ of the global blue wa- ter footprint. Both basins are under severe water stress (Alcamo et al., 2007).

\subsection{The water footprint in irrigated versus rain-fed agriculture}

For most of the crops, the global average consumptive water footprint (blue plus green water footprint) per ton of crop was lower for irrigated crops than for rain-fed crops (Table 8). This is because, on average, irrigated yields are larger than rain-fed yields. For wheat, the water footprint per ton in irrigated and rain-fed agriculture are very similar at the global 


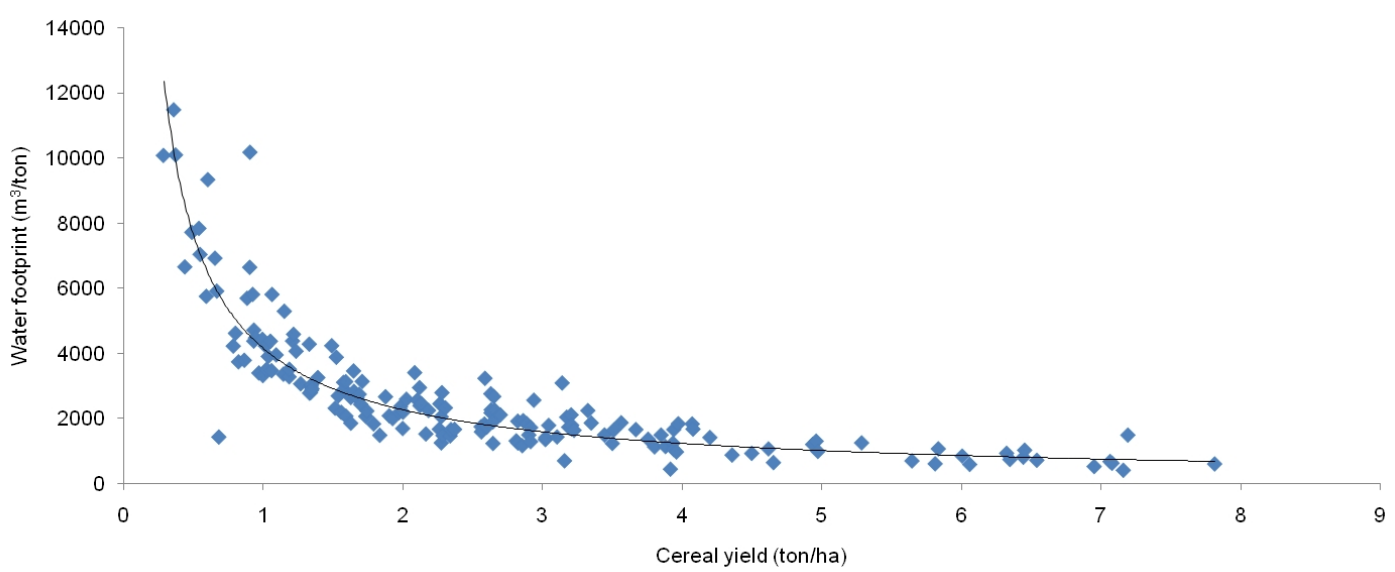

Fig. 4. The relationship between average cereal yield and water footprint per ton of cereal. Period: 1996-2005. The dots represent average country data.

Table 4. Crop water requirement, production, area, yield and water footprint per ton per region for cereal crops (1996-2005).

\begin{tabular}{|c|c|c|c|c|c|c|c|c|c|c|c|c|}
\hline \multirow{2}{*}{ Region } & \multirow{2}{*}{$\begin{array}{l}\text { Crop water } \\
\text { requirement } \\
\left(\mathrm{mm} \mathrm{period}^{-1}\right)\end{array}$} & \multirow{2}{*}{$\begin{array}{l}\text { Total } \\
\text { production } \\
\left(10^{6}\right. \\
\left.\text { ton } \mathrm{yr}^{-1}\right)\end{array}$} & \multirow{2}{*}{$\begin{array}{l}\% \\
\text { irrigated } \\
\text { production }\end{array}$} & \multirow{2}{*}{$\begin{array}{l}\text { Total } \\
\text { area } \\
\left(10^{6}\right. \\
\left.\text { ha yr }^{-1}\right)\end{array}$} & \multirow{2}{*}{$\begin{array}{l}\% \\
\text { irrigated } \\
\text { area }\end{array}$} & \multicolumn{3}{|c|}{ Yield (ton ha ${ }^{-1}$ ) } & \multicolumn{4}{|c|}{ Water footprint $\left(\mathrm{m}^{3} \operatorname{ton}^{-1}\right)$} \\
\hline & & & & & & Rain-fed & Irrigated & average & Green & Blue & Grey & Total \\
\hline Africa & 527 & 122 & 23 & 94 & 7 & 1.08 & 4.25 & 1.30 & 3044 & 243 & 101 & 3388 \\
\hline Central Africa & 448 & 5 & 2 & 6 & 1 & 0.84 & 1.72 & 0.84 & 4616 & 25 & 17 & 4658 \\
\hline Eastern Africa & 561 & 30 & 13 & 24 & 7 & 1.20 & 2.21 & 1.27 & 3572 & 118 & 56 & 3746 \\
\hline Northern Africa & 602 & 35 & 62 & 21 & 19 & 0.80 & 5.36 & 1.68 & 1897 & 672 & 242 & 2811 \\
\hline Southern Africa & 614 & 13 & 13 & 5 & 8 & 2.21 & 3.68 & 2.32 & 1727 & 80 & 119 & 1926 \\
\hline Western Africa & 465 & 39 & 3 & 38 & 1 & 1.02 & 2.82 & 1.03 & 3846 & 40 & 17 & 3903 \\
\hline Asia & 546 & 1014 & 67 & 320 & 53 & 2.22 & 3.99 & 3.17 & 1166 & 379 & 228 & 1774 \\
\hline Central Asia & 492 & 22 & 26 & 17 & 14 & 1.12 & 2.40 & 1.30 & 2272 & 289 & 13 & 2574 \\
\hline Eastern Asia & 475 & 447 & 81 & 91 & 76 & 3.89 & 5.26 & 4.94 & 707 & 238 & 250 & 1195 \\
\hline Middle East & 613 & 6 & 47 & 4 & 25 & 1.07 & 2.87 & 1.53 & 2123 & 543 & 325 & 2991 \\
\hline South-Eastern Asia & 665 & 174 & 47 & 51 & 39 & 2.91 & 4.12 & 3.38 & 1578 & 180 & 154 & 1912 \\
\hline Southern Asia & 549 & 326 & 67 & 139 & 54 & 1.67 & 2.93 & 2.35 & 1421 & 678 & 255 & 2354 \\
\hline Western Asia & 576 & 40 & 28 & 19 & 22 & 1.96 & 2.61 & 2.11 & 1698 & 413 & 189 & 2300 \\
\hline America & 578 & 535 & 19 & 125 & 13 & 3.97 & 6.39 & 4.28 & 1028 & 92 & 174 & 1294 \\
\hline Caribbean & 555 & 2 & 50 & 1 & 32 & 1.51 & 3.17 & 2.04 & 2021 & 325 & 14 & 2359 \\
\hline Central America & 483 & 33 & 34 & 13 & 27 & 2.39 & 3.31 & 2.64 & 1598 & 149 & 261 & 2008 \\
\hline Northern America & 589 & 392 & 19 & 76 & 11 & 4.70 & 8.60 & 5.14 & 828 & 85 & 182 & 1094 \\
\hline South America & 589 & 108 & 15 & 35 & 11 & 2.91 & 4.40 & 3.07 & 1558 & 96 & 123 & 1778 \\
\hline Europe & 470 & 418 & 10 & 125 & 6 & 3.21 & 5.63 & 3.36 & 1054 & 41 & 119 & 1214 \\
\hline Eastern Europe & 492 & 180 & 5 & 79 & 4 & 2.25 & 2.95 & 2.27 & 1645 & 38 & 113 & 1795 \\
\hline Northern Europe & 284 & 47 & 2 & 9 & 2 & 5.16 & 5.73 & 5.17 & 522 & 1 & 114 & 637 \\
\hline Southern Europe & 516 & 70 & 29 & 18 & 16 & 3.18 & 7.07 & 3.81 & 907 & 140 & 170 & 1217 \\
\hline Western Europe & 421 & 121 & 9 & 18 & 6 & 6.62 & 8.99 & 6.77 & 528 & 14 & 111 & 654 \\
\hline Oceania & 624 & 35 & 7 & 18 & 3 & 1.87 & 5.21 & 1.96 & 1787 & 66 & 116 & 1969 \\
\hline World & 538 & 2117 & 41 & 679 & 30 & 2.63 & 4.26 & 3.11 & 1232 & 228 & 184 & 1644 \\
\hline
\end{tabular}

scale. For soybean, sugarcane and rapeseed, the water footprints per ton were substantially smaller in rain-fed production. The reason is that, although yields are higher under irrigation for soybean and sugarcane, there is more water available to meet crop water requirements, leading to an actual evapotranspiration that will approach or equal potential evapotranspiration. Under rain-fed conditions, the actual evapotranspiration over the growing period is generally lower than the potential evapotranspiration. In the case of rapeseed, the global average rain-fed yield is larger than global average 
Table 5. Global average water footprint of biofuel for ten crops providing ethanol and seven crops providing biodiesel. Period: 1996-2005.

\begin{tabular}{|c|c|c|c|c|c|c|}
\hline \multirow{2}{*}{ Crop } & \multicolumn{3}{|c|}{$\begin{array}{l}\text { Water footprint per } \\
\text { unit of energy }\end{array}$} & \multicolumn{3}{|c|}{$\begin{array}{l}\text { Water footprint per } \\
\text { litre of biofuel }\end{array}$} \\
\hline & Green & Blue & Grey & Green & Blue & Grey \\
\hline Crops for ethanol & \multicolumn{3}{|c|}{$\mathrm{m}^{3}$ per GJ ethanol } & \multicolumn{3}{|c|}{ litres water per litre ethanol } \\
\hline Barley & 119 & 8 & 13 & 2796 & 182 & 302 \\
\hline Cassava & 106 & 0 & 3 & 2477 & 1 & 60 \\
\hline Maize & 94 & 8 & 19 & 2212 & 190 & 453 \\
\hline Potatoes & 62 & 11 & 21 & 1458 & 251 & 483 \\
\hline Rice, paddy & 113 & 34 & 18 & 2640 & 785 & 430 \\
\hline Rye & 140 & 2 & 10 & 3271 & 58 & 229 \\
\hline Sorghum & 281 & 10 & 9 & 6585 & 237 & 201 \\
\hline Sugar beet & 31 & 10 & 10 & 736 & 229 & 223 \\
\hline Sugar cane & 60 & 25 & 6 & 1400 & 575 & 132 \\
\hline Wheat & 126 & 34 & 20 & 2943 & 789 & 478 \\
\hline Crops for biodiesel & \multicolumn{3}{|c|}{$\mathrm{m}^{3}$ per GJ biodiesel } & \multicolumn{3}{|c|}{ litres water per litre biodiesel } \\
\hline Coconuts & 4720 & 3 & 28 & 156585 & 97 & 935 \\
\hline Groundnuts & 177 & 11 & 12 & 5863 & 356 & 388 \\
\hline Oil palm & 150 & 0 & 6 & 4975 & 1 & 190 \\
\hline Rapeseed & 145 & 20 & 29 & 4823 & 655 & 951 \\
\hline Seed cotton & 310 & 177 & 60 & 10274 & 5879 & 1981 \\
\hline Soybeans & 326 & 11 & 6 & 10825 & 374 & 198 \\
\hline Sunflower & 428 & 21 & 28 & 14200 & 696 & 945 \\
\hline
\end{tabular}

Table 6. The water footprint of crop production in selected countries (1996-2005).

\begin{tabular}{lrrrr}
\hline \multirow{2}{*}{ Country } & \multicolumn{4}{c}{ Water footprint of crop } \\
& \multicolumn{3}{c}{ production $\left(\mathrm{Gm}^{3} \mathrm{yr}^{-1}\right)$} \\
\cline { 2 - 5 } & Green & Blue & Grey & Total \\
\hline India & 716.0 & 231.4 & 99.4 & 1047 \\
China & 623.9 & 118.9 & 223.8 & 967 \\
USA & 612.0 & 95.9 & 118.2 & 826 \\
Brazil & 303.7 & 8.9 & 16.0 & 329 \\
Russia & 304.8 & 10.4 & 11.6 & 327 \\
Indonesia & 285.5 & 11.5 & 20.9 & 318 \\
Nigeria & 190.6 & 1.1 & 0.6 & 192 \\
Argentina & 157.6 & 4.3 & 5.0 & 167 \\
Canada & 120.3 & 1.6 & 18.2 & 140 \\
Pakistan & 40.6 & 74.3 & 21.8 & 137 \\
\hline World & 5771 & 899 & 733 & 7404 \\
\hline
\end{tabular}

irrigated yield which results in a smaller water footprint under rain-fed compared to irrigated crops. The reason for this is that those countries with a high yield happen to be countries with a large share of rain-fed harvested crop area. For example, a high crop yield is observed for rapeseed in most parts of Western Europe, where rapeseed is almost com-
Table 7. The water footprint of crop production in selected river basins (1996-2005).

\begin{tabular}{lrrrr}
\hline \multirow{2}{*}{ River basin* } & \multicolumn{4}{c}{ Water footprint of crop } \\
& \multicolumn{4}{c}{ production $\left(\mathrm{Gm}^{3} \mathrm{yr}^{-1}\right)$} \\
\cline { 2 - 5 } & Green & Blue & Grey & Total \\
\hline Mississippi & 424 & 40 & 70 & 534 \\
Ganges & 260 & 108 & 39 & 408 \\
Yangtze (Chang Jiang) & 177 & 18 & 61 & 256 \\
Indus & 102 & 117 & 34 & 253 \\
Parana & 237 & 3.2 & 9.4 & 250 \\
Niger & 186 & 1.7 & 0.5 & 188 \\
Nile & 131 & 29 & 6.9 & 167 \\
Huang He (Yellow River) & 80 & 21 & 31 & 132 \\
Nelson & 108 & 1.5 & 18 & 128 \\
Danube & 106 & 1.8 & 11 & 119 \\
Krishna & 89 & 21 & 8.7 & 118 \\
Volga & 101 & 3.4 & 3.9 & 108 \\
Ob & 92 & 1.8 & 1.8 & 95 \\
\hline World & 5771 & 899 & 733 & 7404 \\
\hline
\end{tabular}

* River basins grid data from Global Runoff Data Centre (2007).

pletely rain-fed. On the other hand, in countries such as Algeria, Pakistan and India, where the share of irrigated crop is high, the irrigated yield is quite low compared to the rain-fed 
yield in Western Europe. Globally, rain-fed agriculture has a water footprint of $5173 \mathrm{Gm}^{3} \mathrm{yr}^{-1}$ (91\% green, $9 \%$ grey); irrigated agriculture has a water footprint of $2230 \mathrm{Gm}^{3} \mathrm{yr}^{-1}$ (48\% green, $40 \%$ blue, $12 \%$ grey).

\section{Discussion}

In order to compare our estimates with previous studies, we have selected those studies which estimated the water footprint in global crop production and made an explicit distinction between green and blue water (Table 9). The study by Chapagain and Hoekstra (2004) did not take a grid-based approach and also did not make the green-blue distinction per crop and per country, unlike the current study and the studies by Rost et al. (2008), Liu and Yang (2010), Siebert and Döll (2010) and Hanasaki et al. (2010).

A comparison of our estimates with earlier studies shows that the order of magnitude is similar in all studies. The estimate of the total water footprint related to crop production by Hanasaki et al. (2010) is $6 \%$ higher than our estimate, while the estimate of Liu and Yang (2010) is $11 \%$ lower. Our study is at the high side regarding the estimation of the global green water footprint and at the low side regarding the blue water footprint. Although there are major differences in applied models and assumptions, the models agree on the dominant role of green water in global crop production. The study by Rost et al. (2008) gives a higher green water footprint than the other studies, but this can be explained by the fact that evapotranspiration from croplands is estimated here over the whole year, instead of over the growing periods of the crops. The estimate of the total water footprint related to crop production by Fader et al. (2011) is only $4 \%$ higher than our estimate. The differences in the outcomes of the various studies can be due to a variety of causes, including: type of model, spatial resolution, period considered and data regarding cultivated and irrigated areas, growing periods, crop parameters, soil and climate.

Chapagain and Hoekstra (2004) have estimated the global water footprint of crop production distinguishing between green and blue only at the global level, but not per country and per crop. Our estimate of the total (green plus blue) water footprint is $4 \%$ higher than that of Chapagain and Hoekstra (2004). The total water footprint per country estimated in the current study compares reasonably well with the estimates by Chapagain and Hoekstra (2004), with an $r^{2}$ value of 0.96 (Fig. 5a). The trend line almost fits the 1:1 line. The close agreement between the two studies and the slightly higher estimate in the current study is surprising. Due to limited data availability at the time, Chapagain and Hoekstra (2004) estimated crop water consumption based on the assumption of no water stress, so that actual equals potential evapotranspiration and their estimate is expected to be at the high side. There could be a number of reasons for the lower estimate in Chapagain and Hoekstra (2004). Some of the dif- ferences are observed in the larger countries such as the USA, Russia, China and Brazil. Chapagain and Hoekstra (2004) have taken national average climatic data to calculate crop evapotranspiration, which in particular for the large countries mentioned above has led to a different estimate compared to the current study. There are also differences between the two studies in the planting and harvesting dates and thus the length of growing period for the different crops considered.

The estimate of the total water footprint by Liu and Yang (2010) is $11 \%$ lower than our estimate. The reason for the difference probably lies in the number of crops explicitly considered in the two studies: in the current study we have considered 146 crops explicitly while Liu and Yang (2010) have considered 20 crops and grouped the rest into 2 broad crop categories. In Fig. 5b, the total (green plus blue) water footprints by country as estimated in the current study are plotted against the results from Liu and Yang (2010). There is a close agreement between the two studies with an $r^{2}$ value of 0.96. The differences between the two studies can be partially explained by differences in the method used to estimate reference evapotranspiration. The blue water footprint per country as computed in this study compares to the result from Liu and Yang (2010) as shown in Fig. 6a. The correlation is reasonably well, with an $r^{2}$ value of 0.78 .

The computed total (green plus blue) water footprint is almost the same as the value found by Siebert and Döll (2010). However, the green water footprint estimated by Siebert and Döll (2010) is $4.6 \%$ lower than in the current study, while their blue water footprint estimate is $31 \%$ higher. At country level, the blue water footprint estimates in the two studies correlate well, with an $r^{2}$ value of 0.99 , but our estimates are consistently lower (Fig. 6b). For most crops there is a good agreement between the current estimate of the total blue water footprint and the one by Siebert and Döll (2010). However, their total blue water footprint estimate for rice $\left(307 \mathrm{Gm}^{3} \mathrm{yr}^{-1}\right)$ is $52 \%$ higher than our estimate $\left(202 \mathrm{Gm}^{3} \mathrm{yr}^{-1}\right)$. The reason for the difference could be differences in the planting and harvesting dates and thus the length of the growing period in the two studies.

The national blue water footprints estimated in the current study were further compared with statistics on agricultural water withdrawals per country as available from AQUASTAT (FAO, 2008b). Since water withdrawals are higher than actual blue water consumption, we first estimated the latter by multiplying the water withdrawal per country by the irrigation efficiency. Overall irrigation efficiency data per country were obtained from Rohwer et al. (2007), whereby irrigation efficiency refers here to the fraction of water diverted from the water source that is available for beneficial crop evapotranspiration. The blue water footprint per country computed in the current study generally compares well with the derived values based on AQUASTAT and Rohwer et al. (2007), with an $r^{2}$ value of 0.94 (Fig. 7a). Compared to the AQUASTAT values, our estimates are slightly lower $(6 \%)$. A reason may be that water withdrawals in agriculture do not refer 
Table 8. The water footprint of rain-fed and irrigated agriculture for selected crops (1996-2005).

\begin{tabular}{|c|c|c|c|c|c|c|c|c|c|c|}
\hline \multirow[t]{2}{*}{ Crop } & \multirow[t]{2}{*}{$\begin{array}{l}\text { Farming } \\
\text { system }\end{array}$} & \multirow[t]{2}{*}{$\begin{array}{l}\text { Yield } \\
\left.\text { (ton ha }^{-1}\right)\end{array}$} & \multicolumn{4}{|c|}{$\begin{array}{l}\text { Total water footprint related to } \\
\text { crop production }\left(\mathrm{Gm}^{3} \mathrm{yr}^{-1}\right)\end{array}$} & \multicolumn{4}{|c|}{$\begin{array}{l}\text { Water footprint per ton } \\
\text { of crop }\left(\mathrm{m}^{3} \text { ton }^{-1}\right)\end{array}$} \\
\hline & & & Green & Blue & Grey & Total & Green & Blue & Grey & Total \\
\hline \multirow{3}{*}{ Wheat } & Rain-fed & 2.48 & 610 & 0 & 65 & 676 & 1629 & 0 & 175 & 1805 \\
\hline & Irrigated & 3.31 & 150 & 204 & 58 & 411 & 679 & 926 & 263 & 1868 \\
\hline & Global & 2.74 & 760 & 204 & 123 & 1087 & 1278 & 342 & 208 & 1828 \\
\hline \multirow{3}{*}{ Maize } & Rain-fed & 4.07 & 493 & 0 & 85 & 579 & 1082 & 0 & 187 & 1269 \\
\hline & Irrigated & 6.01 & 104 & 51 & 37 & 192 & 595 & 294 & 212 & 1101 \\
\hline & Global & 4.47 & 597 & 51 & 122 & 770 & 947 & 81 & 194 & 1222 \\
\hline \multirow{3}{*}{ Rice } & Rain-fed & 2.69 & 301 & 0 & 30 & 331 & 1912 & 0 & 190 & 2102 \\
\hline & Irrigated & 4.67 & 378 & 202 & 81 & 661 & 869 & 464 & 185 & 1519 \\
\hline & Global & 3.90 & 679 & 202 & 111 & 992 & 1146 & 341 & 187 & 1673 \\
\hline \multirow{3}{*}{ Apples } & Rain-fed & 8.93 & 24 & 0 & 6 & 30 & 717 & 0 & 167 & 883 \\
\hline & Irrigated & 15.91 & 8 & 8 & 2 & 18 & 343 & 321 & 71 & 734 \\
\hline & Global & 10.92 & 33 & 8 & 7 & 48 & 561 & 133 & 127 & 822 \\
\hline \multirow{3}{*}{ Soybean } & Rain-fed & 2.22 & 328 & 0 & 5 & 333 & 2079 & 0 & 33 & 2112 \\
\hline & Irrigated & 2.48 & 24 & 12 & 1 & 37 & 1590 & 926 & 85 & 2600 \\
\hline & Global & 2.24 & 351 & 12 & 6 & 370 & 2037 & 70 & 37 & 2145 \\
\hline \multirow{3}{*}{ Sugarcane } & Rain-fed & 58.70 & 95 & 0 & 7 & 102 & 164 & 0 & 13 & 176 \\
\hline & Irrigated & 71.17 & 85 & 74 & 10 & 169 & 120 & 104 & 14 & 238 \\
\hline & Global & 64.96 & 180 & 74 & 17 & 271 & 139 & 57 & 13 & 210 \\
\hline \multirow{3}{*}{ Coffee } & Rain-fed & 0.68 & 106 & 0 & 4 & 110 & 15251 & 0 & 523 & 15774 \\
\hline & Irrigated & 0.98 & 1 & 1 & 0 & 2 & 8668 & 4974 & 329 & 13971 \\
\hline & Global & 0.69 & 108 & 1 & 4 & 112 & 15249 & 116 & 532 & 15897 \\
\hline \multirow{3}{*}{ Rapeseed } & Rain-fed & 1.63 & 62 & 0 & 12 & 74 & 1783 & 0 & 356 & 2138 \\
\hline & Irrigated & 1.23 & 4 & 9 & 1 & 14 & 1062 & 2150 & 181 & 3394 \\
\hline & Global & 1.57 & 66 & 9 & 13 & 88 & 1703 & 231 & 336 & 2271 \\
\hline \multirow{3}{*}{ Cotton } & Rain-fed & 1.35 & 90 & 0 & 13 & 103 & 3790 & 0 & 532 & 4321 \\
\hline & Irrigated & 2.16 & 41 & 75 & 13 & 129 & 1221 & 2227 & 376 & 3824 \\
\hline & Global & 1.73 & 132 & 75 & 25 & 233 & 2282 & 1306 & 440 & 4029 \\
\hline \multirow{3}{*}{ All crops } & Rain-fed & - & 4701 & 0 & 472 & 5173 & - & - & - & - \\
\hline & Irrigated & - & 1070 & 899 & 261 & 2230 & - & - & - & - \\
\hline & Global & - & 5771 & 899 & 733 & 7404 & - & - & - & - \\
\hline
\end{tabular}

to withdrawals alone; water withdrawn for domestic needs and animal breeding may constitute $5-8 \%$ of the agricultural water withdrawal (Shiklomanov, 2000). Assuming that water withdrawal for irrigation equals agricultural water withdrawal may thus lead to a slight overestimation of the blue water footprint from the statistics.

The blue water footprints estimated in the current study can also be compared with consumptive water use in irrigation on the level of federal states in the USA. Hutson et al. (2004) provide irrigation water withdrawal at federal state level for the year 2000. Consumptive blue water use for the year 2000 was derived using the ratio of consumptive water use to water withdrawal for irrigation at state level for the year 1995 (Solley et al., 1998). Our estimated blue water footprints at federal state level correlate well with the statistic data, at least for states with high irrigation water use. The blue water footprints at the state level obtained in the current study, however, are generally lower than the values obtained from the statistics (Fig. 7b).

The calculated national blue water footprints were further compared to the irrigation water requirements for 90 developing countries as estimated by FAO (2005) for the year 2000. As can be seen in Fig. 8, the calculated national blue water footprints are consistently lower than the national irrigation requirements from FAO (2005), which can be explained by the use of different land use data and differences 
Table 9. Comparison between the results from the current study and the results from previous studies.

\begin{tabular}{lrrrr}
\hline \multicolumn{1}{c}{ Study } & Period & \multicolumn{3}{c}{$\begin{array}{c}\text { Global water footprint related to } \\
\text { crop production }\left(\mathrm{Gm}^{3} \mathrm{yr}^{-1}\right)\end{array}$} \\
\cline { 3 - 5 } & & Green & Blue & Total \\
\hline Chapagain and Hoekstra (2004), & & & & \\
Hoekstra and Chapagain (2007), & & & & \\
Hoekstra and Chapagain (2008) & $1997-2001$ & 5330 & 1060 & 6390 \\
Rost et al. (2008) & $1971-2000$ & $7250^{*}$ & $600-1258$ & $7850-8508^{*}$ \\
Liu and Yang (2010) & $1998-2002$ & 4987 & 951 & 5938 \\
Siebert and Döll (2010) & $1998-2002$ & 5505 & 1180 & 6685 \\
Hanasaki et al. (2010) & $1985-1999$ & 5550 & 1530 & 7080 \\
Fader et al. (2011) & $1998-2002$ & 6000 & 923 & 6923 \\
Current study, green \& blue only & $1996-2005$ & 5771 & 899 & 6670 \\
\hline
\end{tabular}

* Unlike the other values, this value includes the evapotranspiration from cropland outside the growing period.

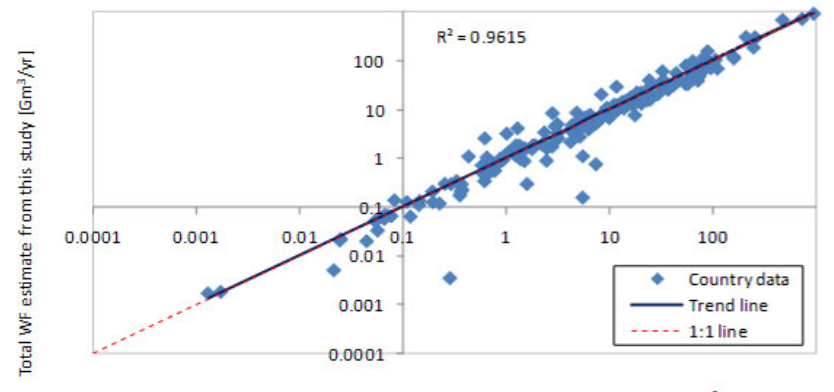

(a)

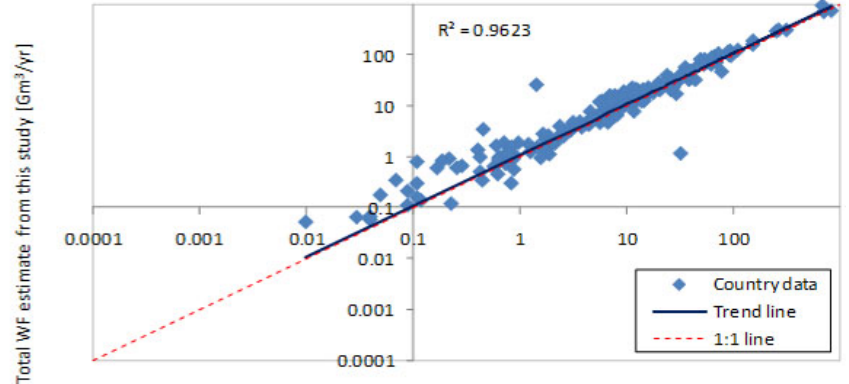

(b)
Total WF estimate by Liu and Yang (2010) $[\mathrm{Gm} / 3 / \mathrm{yr}]$

Fig. 5. Comparison of national (green plus blue) water footprints related to crop production as estimated in the current study with results from (a) Chapagain and Hoekstra (2004), and (b) Liu and Yang (2010).

in model set-up in the two studies. In the current study, the soil water balance was made on a daily basis while in FAO (2005) the soil water balance was done with a monthly time step. Besides, for rice irrigation water requirements, FAO (2005) added an additional $250 \mathrm{~mm}$ of water to flood the paddy fields.

The water footprint per ton of crop has been compared with results from Chapagain and Hoekstra (2004) and Siebert and Döll (2010). The global average water footprint per ton of crop correlates well with Chapagain and Hoekstra (2004), with an $r^{2}$ value of 0.97 (Fig. 9a). The comparison with Siebert and Döll (2010) also shows a good agreement, with an $r^{2}$ value of 0.995 (Fig. 9b). Out of the 22 crops compared, for 13 crops (including wheat, rice, maize, barley and sugar cane) the difference is within $\pm 10 \%$. Large differences $( \pm 20 \%)$ were observed for rye, cassava and millet. The reason for the larger differences probably lies in the average yield used in the two studies. We used national average yield data from FAOSTAT, which apparently differ from the yield data from Monfreda et al. (2008) which were used by Siebert and Döll (2010).
Since all studies depend on a large set of assumptions with respect to modelling structure, parameter values and datasets used, as it was already pointed out by Mekonnen and Hoekstra (2010), it is difficult to attribute differences in estimates from the various studies to specific factors; also it is difficult to assess the quality of our new estimates relative to the quality of earlier estimates. The quality of data used defines the accuracy of the model output. All studies suffer the same sorts of limitations in terms of data availability and quality and deal with that in different ways. In future studies it would be useful to spend more effort in studying the sensitivity of the model outcomes to assumptions and parameters and assessing the uncertainties in the final outcome.

\section{Conclusions}

The study shows that the global water footprint of crop production for the period 1996-2005 was $7404 \mathrm{Gm}^{3} \mathrm{yr}^{-1}$. The large fraction of green water $(78 \%)$ confirms the importance of green water in global food production. The fraction of blue water is smaller (12\%), but as the spatial analysis shows, the 


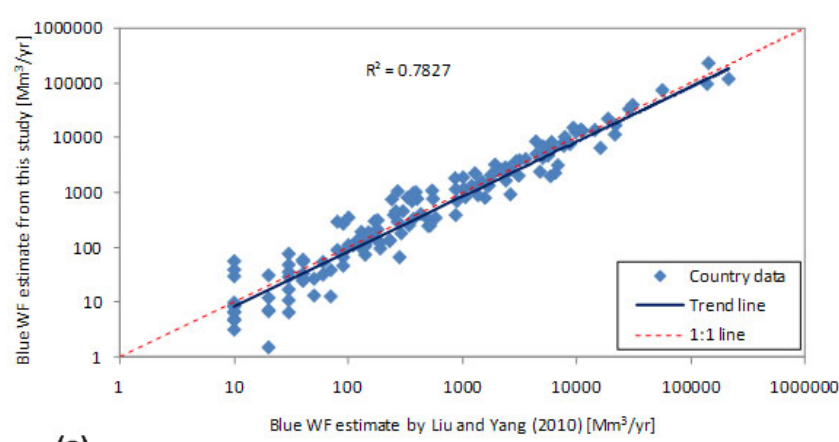

(a)

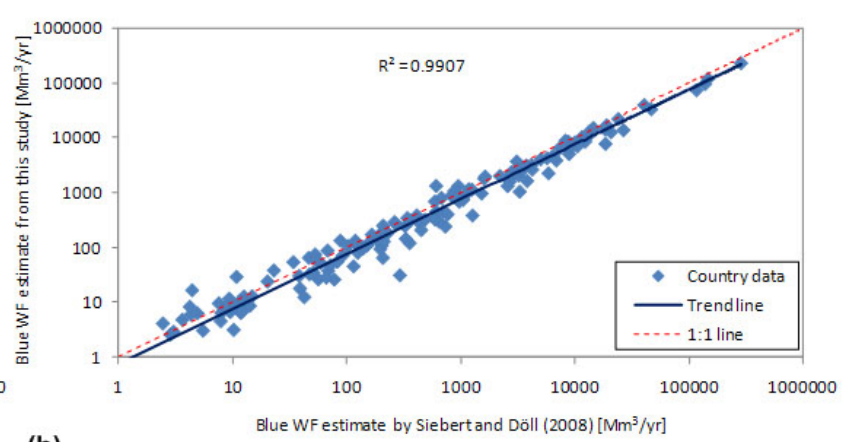

(b)

Fig. 6. Comparison of national blue water footprints related to crop production as estimated in the current study with results from (a) Liu and Yang (2010) and (b) Siebert and Döll (2008).

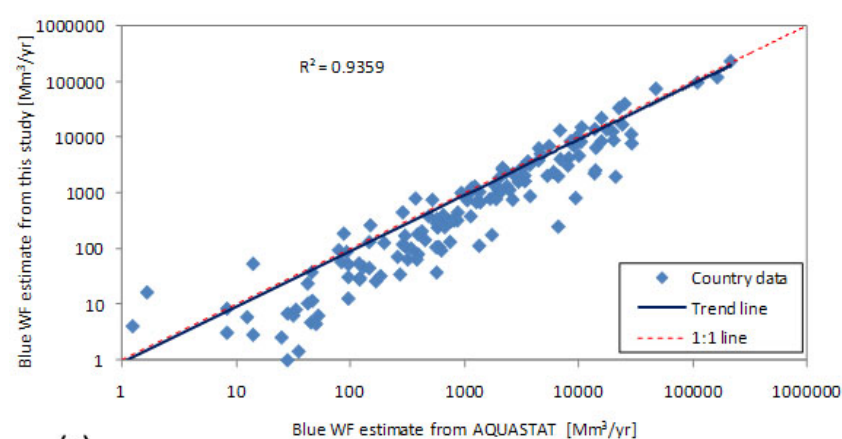

(a)

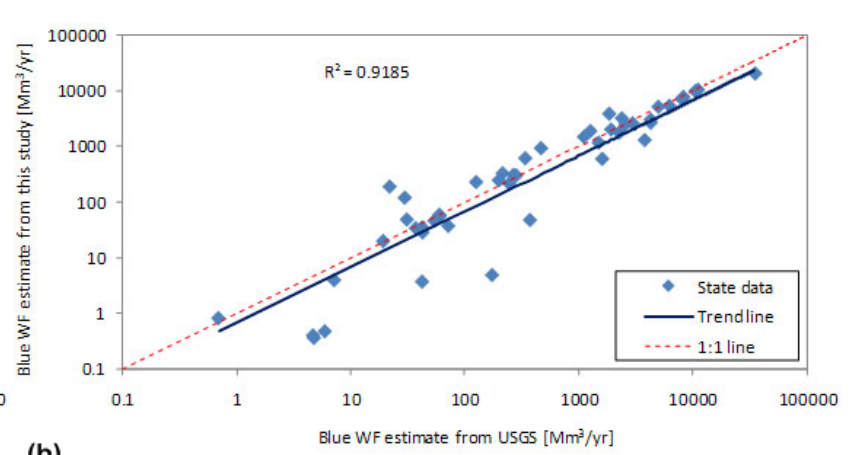

(b)

Fig. 7. Comparison of blue water footprints related to crop production as estimated in the current study with results from (a) AQUASTAT (FAO, 2008b) for developing countries, and (b) USGS (Hutson et al., 2004; Solley et al., 1998) for the states in the USA.

regions where blue water footprints are large are often arid and semi-arid regions where water scarcity is high. The share of the grey water footprint is relatively small as well (10\%), but this is a conservative estimate, because we have analysed the required assimilation volume for leached nitrogen fertilizers only, leaving out relevant pollutants such as phosphorus and pesticides.

The finding in this study agrees with earlier studies that green water plays a prominent role in the global crop production. As shown by Rockström et al. (2009), most countries in theory have a green water based self-sufficiency potential and are in a position to produce their entire food requirement locally. Rockström et al. (2003) showed that there is great opportunity to improve water productivity through improving yield levels as much as four folds within the available water balance in rain-fed agriculture. This offers a good opportunity to increase food production from rain-fed agriculture by raising water productivity without requiring additional blue water resources (Critchely and Siegert, 1991; Rockström and Barron, 2007; Rockström et al., 2003, 2007a, b). However, the marginal benefit of additional blue water in semi-arid and arid regions is quite large in terms of raising productivity. Globally, the current cereal production would be significantly lower if no blue water is applied (Hoff et al., 2010; Rost et al., 2009; Siebert and Döll, 2010). Therefore, a carefully balanced green-blue water use strategy would be required to address the issue of increasing water demand in a world of limited freshwater resources. For further research it is important to assess the spatiotemporal variability of blue water availability and how much blue water can sustainably be used in a certain catchment without adversely affecting the ecosystem.

There are a number of uncertainties in the estimation of the green, blue and grey water footprints. In particular, the uncertainties related to the input data used in the model are high. A number of assumptions were made due to a lack of data. The uncertainties include:

- Crop-specific irrigation maps are available only for a limited number of crops. Irrigation maps for the other crops were derived from the MICRA2000 database through the simple assumption that all crops in a country belonging to a certain crop category (annuals/perennials) would have the same fraction of irrigated area out of the total harvested area. This assumption will lead to an underestimation of the irrigated area and thus the blue water footprint of crops which are most 


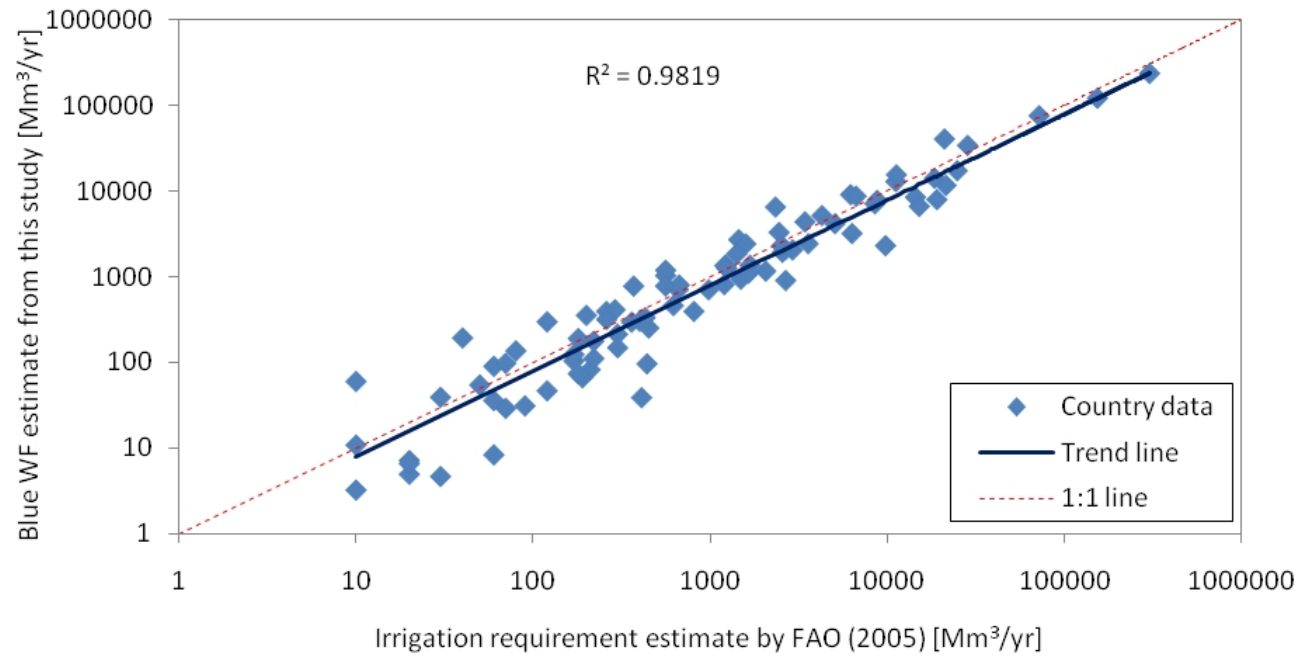

Fig. 8. Comparison of national blue water footprints related to crop production as estimated in the current study with national irrigation requirements as estimated by FAO (2005).

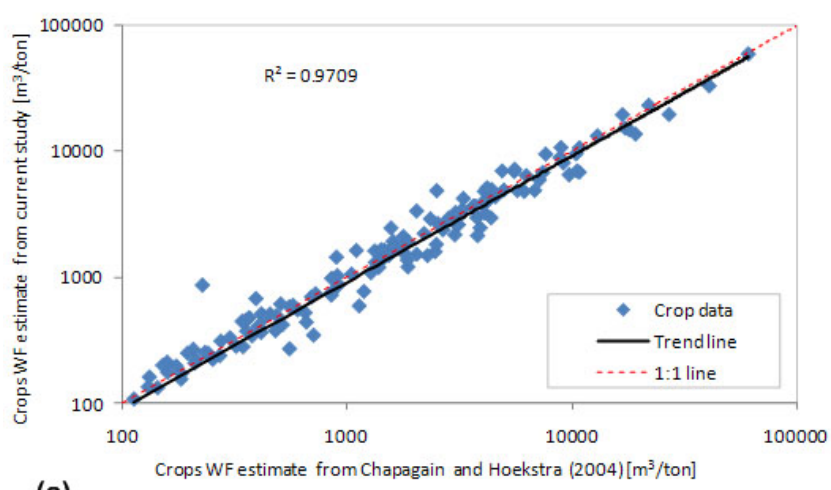

(a)

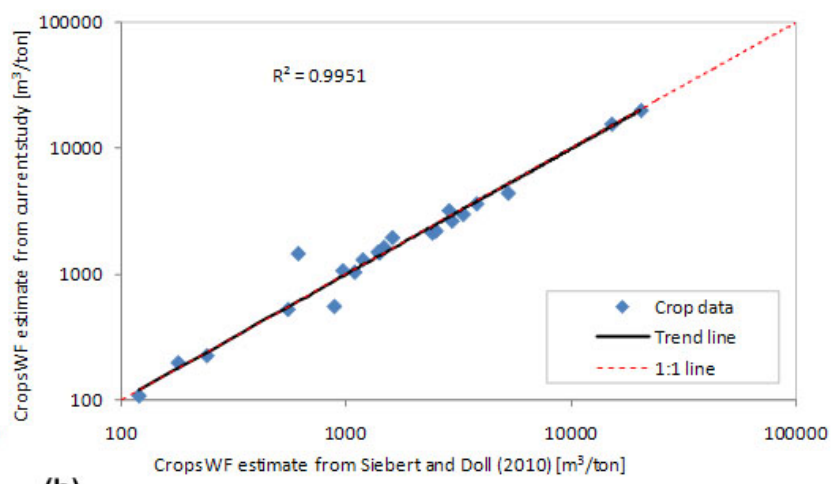

(b)

Fig. 9. Comparison of global average crops water footprint (green plus blue) as estimated in the current study with results from (a) Chapagain and Hoekstra (2004), and (b) Siebert and Döll (2008).

likely to be irrigated and an overestimation of the blue water footprint for those minor crops which are actually not irrigated.

- The planting and harvesting dates and thus the length of the growing period used in the study are available only at country level, thus do not reflect possible variation within a country and across varieties of the same crop. Crop planting and harvesting dates are provided in the literature as a range of dates (FAO, 2008d; USDA, 1994). The choice of the planting and harvesting dates out of these ranges obviously influences the final crop water footprint estimate.

- The rooting depth for both rain-fed and irrigated crops are defined based on the crop characteristics. However, such assumption neglects the fact that actual rooting depth depends also on the soil type.
- The soil water holding capacity is derived based on the dominant soil type. However, farmers may plant in the parts of the grid cell with better soils, which may have a different water holding capacity to that defined for the dominant soil type.

- For irrigated agriculture, the irrigation is assumed to be sufficient to meet the irrigation requirement. However, farmers may decide to supply irrigation water below the level of optimal yield, in particular in those regions where water is scarce. The assumption of sufficient irrigation may lead to an overestimation of the blue water footprint.

- Fertilizer application rates per crop per country are not available for most crops. The rates used in this study are based on different sources and a number of assumptions. All grid cells of the same crop in a country are 
assumed to receive the same fertilizer application rate. However, irrigated crops generally receive more fertilizer than rain-fed ones. Besides, most small subsistence farmers likely use no or less fertilizer.

- The grey water footprint is estimated based on a simplified approach, which gives a rough estimate; it leaves out local factors that influence the precise leaching and runoff rates, such as rainfall intensity, soil property, slopes and the amount of already mineralized nitrogen in the upper soil layer. Systematic comparison of the estimate from such simplified approach with other regression models (De Willigen, 2000; Roy et al., 2003; Liu et al., 2010) might be required to test the uncertainties and limitation of our approach. Liu et al. (2010) estimated, for the first time, global nitrogen flows of 6 nitrogen inputs and 5 nitrogen outputs including nitrogen leaching at high resolution ( 5 by 5 arc minute grid). Their approach is very innovative and could be useful to conduct in-depth grey water assessment in the future.

- The model used to estimate the yield at grid level is a simplified linear model which accounts for the effect of water deficit on yield reduction only, leaving out other factors, such as fertilizer application rate, soil salinity and crop growing characteristics.

- Although intercropping and multi-cropping are practiced in most part of the world, we have not considered those practices explicitly.

In a global study like this one, because of lack of data, several assumptions and expert guesses were made. At this stage it seems difficult to reduce the uncertainties. Therefore, the water footprint values at a smaller spatial scale, in particular at the grid cell level, should be interpreted with care.

Edited by: J. Liu

\section{References}

Alcamo, J., Flörke, M., and Märker, M.: Future long-term changes in global water resources driven by socio-economic and climatic changes, Hydrolog. Sci. J., 52(2), 247-275, 2007.

Allen, R. G., Pereira, L. S., Raes, D., and Smith, M.: Crop evapotranspiration: guidelines for computing crop water requirements, FAO Drainage and Irrigation Paper 56, Food and Agriculture Organization, Rome, 1998.

Alptekin, E. and Canakci, M.: Determination of the density and the viscosities of biodiesel-diesel fuel blends, Renew. Energ., 33(12), 2623-2630, 2008.

Batjes, N. H.: ISRIC-WISE derived soil properties on a 5 by 5 arcminutes global grid, Report 2006/02, ISRIC - World Soil Information, Wageningen, The Netherlands, available at: www.isric. org, 2006.
Chapagain, A. K. and Hoekstra, A. Y.: Water footprints of nations, Value of Water Research Report Series No. 16, UNESCO-IHE, Delft, The Netherlands, 2004.

Chapagain, A. K., Hoekstra, A. Y., Savenije, H. H. G., and Gautam, R.: The water footprint of cotton consumption: an assessment of the impact of worldwide consumption of cotton products on the water resources in the cotton producing countries, Ecol. Econ., 60(1), 186-203, 2006.

Critchley, W. and Siegert, K.: Water harvesting: A manual for the design and construction of water harvesting schemes for plant production, Food and Agriculture Organization, Rome, 1991.

De Willigen, P.: An analysis of the calculation of leaching and denitrification losses as practised in the NUTMON approach, Plant Research International, Wageningen, The Netherlands, 2000.

Döll, P. and Siebert, S.: Global modelling of irrigation water requirements. Water Resour. Res., 38(4), 1037, doi:10.1029/2001WR000355, 2002.

Doorenbos, J. and Kassam, A. H.: Yield response to water, FAO Drainage and Irrigation Paper 33, FAO, Rome, 1979.

Fader, M., Gerten, D., Thammer, M., Heinke, J., Lotze-Campen, H., Lucht, W., and Cramer, W.: Internal and external green-blue agricultural water footprints of nations, and related water and land savings through trade, Hydrol. Earth Syst. Sci. Discuss., 8, 483527, doi:10.5194/hessd-8-483-2011, 2011.

FAO: Technical conversion factors for agricultural commodities, Food and Agriculture Organization, Rome, 2003.

FAO: Review of agricultural water use per country, Food and Agriculture Organization, Rome, available at: www.fao.org/nr/water/ aquastat/water_use_agr/index.stm, 2005.

FAO: Fertilizer use by crop, FAO Fertilizer and Plant Nutrition Bulletin 17, Food and Agriculture Organization, Rome, 2006.

FAO: FAOSTAT on-line database, Food and Agriculture Organization, Rome, http://faostat.fao.org, last access: 10 October 2008a.

FAO: AQUASTAT on-line database, Food and Agriculture Organization, Rome, http://faostat.fao.org last access: 10 October 2008 b.

FAO: Global map of monthly reference evapotranspiration - 10 arc minutes, GeoNetwork: grid database, Food and Agriculture Organization, Rome, http://www.fao.org/geonetwork/srv/ en/resources.get?id=7416 \\&fname=ref_evap_fao_10min.zip $\backslash$ \&access=private, last access: 15 October $2008 \mathrm{c}$.

FAO: Global Information and Early Warning System (GIEWS) - Crop calendar tool, Food and Agriculture Organization, Rome, http://lprapp08.fao.org/fenix-portal last access: 15 October 2008d.

FAO: FertiStat - Fertilizer use statistics. Food and Agriculture Organization, Rome, www.fao.org/ag/agl/fertistat/, last access: 10 February 2009.

Gerbens-Leenes, P. W., Hoekstra, A. Y., and Van der Meer, T. H.: The water footprint of bio-energy: Global water use for bioethanol, bio-diesel, heat and electricity, Value of Water Research Report Series No. 29, UNESCO-IHE, Delft, The Netherlands, 2008a.

Gerbens-Leenes, P. W., Hoekstra, A. Y., and Van der Meer, T.H.: Water footprint of bio-energy and other primary energy carriers, Value of Water Research Report Series No. 34, UNESCO-IHE, Delft, The Netherlands, 2008b.

Gerbens-Leenes, W., Hoekstra, A. Y., and Van der Meer, T. H.: The water footprint of bioenergy, P. Natl. Acad. Sci. USA, 106(25), 
10219-10223, 2009.

Gleick, P. H. (Ed.): Water in crisis: A guide to the world's fresh water resources, Oxford University Press, Oxford, UK, 1993.

Gleick, P. H.: The changing water paradigm: a look at twenty-first century water resources development, Water Inter., 25(1),127$138,2000$.

Global Runoff Data Centre Major River Basins of the World, Global Runoff Data Centre, Koblenz, Federal Institute of Hydrology (BfG), Germany, 2007.

Hanasaki, N., Inuzuka, T., Kanae, S., and Oki, T. An estimation of global virtual water flow and sources of water withdrawal for major crops and livestock products using a global hydrological model, J. Hydrol., 384, 232-244, 2010.

Heffer, P.: Assessment of Fertilizer Use by Crop at the Global Level 2006/2007-2007/2008. International Fertilizer Industry Association, Paris, 2009.

Hoekstra, A. Y. (Ed.): Virtual water trade: Proceedings of the International Expert Meeting on Virtual Water Trade, Delft, The Netherlands, 12-13 December 2002, Value of Water Research Report Series No. 12, UNESCO-IHE, Delft, The Netherlands, 2003.

Hoekstra, A. Y. and Chapagain, A. K.: Water footprints of nations: water use by people as a function of their consumption pattern, Water Resour. Manag., 21(1), 35-48, 2007.

Hoekstra, A. Y. and Chapagain, A. K.: Globalization of water: Sharing the planet's freshwater resources, Blackwell Publishing, Oxford, UK, 2008.

Hoekstra, A. Y. and Hung, P. Q.: Virtual water trade: A quantification of virtual water flows between nations in relation to international crop trade. Value of Water Research Report Series No. 11, UNESCO-IHE, Delft, The Netherlands, 2002.

Hoekstra, A. Y., Chapagain, A. K., Aldaya, M. M., and Mekonnen, M. M.: The water footprint assessment manual: Setting the global standard, Earthscan, London, UK, 2011.

Hoff, H., Falkenmark, M., Gerten, D., Gordon, L., Karlberg, L., and Rockström, J.: Greening the global water system, J. Hydrol., 384, 177-186, 2010.

Hutson, S. S., Barber, N. L., Kenny, J. F., Linsey, K. S., Lumia, D. S., and Maupin, M. A.: Estimated Use of Water in the United States in 2000, USGS Circular 1268, US Geological Survey, Reston, USA, available at: http://water.usgs.gov/watuse, last access: 15 February 2010, 2004.

IFA: International Fertilizer Industry Association Databank, www. fertilizer.org/ifa/ifadata/results, last access: 24 September 2009.

L'vovich, M. I., White, G. F., and Turner, B. L. I.: Use and transformation of terrestrial water systems, in: The earth as transformed by human action: Global and regional changes in the biosphere over the past 300 years edited by: Turner II, B. L., Clark, W. C, Kates, R. W., Richards, J. F., Mathews, J. T., and Meyer, W. B., Cambridge University Press, New York, 235-252, 1990.

Liu, J. and Yang, H.: Spatially explicit assessment of global consumptive water uses in cropland: green and blue water, J. Hydrol., 384, 187-197, 2010.

Liu, J., Yang, H., and Savenije, H. H. G.: China's move to highermeat diet hits water security, Nature, 454, p. 397, 2008.

Liu, J., Zehnder, A. J. B., and Yang, H.: Global consumptive water use for crop production: The importance of green water and virtual water, Water Resour. Res., 45, W05428, doi:10.1029/2007WR006051, 2009.
Liu, J., You, L., Amini, M., Obersteiner, M., Herrero, M., Zehnder, A. J. B., and Yang, H.: A high-resolution assessment on global nitrogen flows in cropland, P. Natl. Acad. Sci. USA, 107(17), 8035-8040, 2010.

Mekonnen, M. M. and Hoekstra, A. Y.: A global and highresolution assessment of the green, blue and grey water footprint of wheat, Hydrol. Earth Syst. Sci., 14, 12590-1276, doi:10.5194/hess-14-1259-2010, 2010.

Mitchell, T. D. and Jones, P. D.: An improved method of constructing a database of monthly climate observations and associated high-resolution grids, Int. J. Climatol., 25, 693-712, available at: http://cru.csi.cgiar.org/continent_selection.asp, last access: 3 October 2008, 2005.

Monfreda, C., Ramankutty, N., and Foley, J. A.: Farming the planet: 2. Geographic distribution of crop areas, yields, physiological types, and net primary production in the year 2000, Global Biogeochem. Cy., 22, GB1022, doi:10.1029/2007GB002947, available at: www.geog.mcgill.ca/landuse/pub/Data/175crops2000/, last access: 18 September 2008.

Perry, C.: Efficient irrigation; inefficient communication; flawed recommendations, Irrig. and Drain., 56, 367-378, doi:10.1002/ird.323, 2007.

Pimentel, D., Houser, J., Preiss, E., White, O. Fang, H., Mesnick, L., Barsky, T., Tariche, S., Schreck, J., and Alpert, S.: Water resources: Agriculture, the environment, and society, BioScience, 47(2), 97-106, 1997.

Pimentel, D., Berger, B., Filiberto, D., Newton, M., Wolfe, B., Karabinakis, E., Clark, S., Poon, E., Abbett, E., and Nandagopal, S.: Water resources: Agricultural and environmental issues, BioScience, 54(10), 909-918, 2004.

Portmann, F. T., Siebert, S., and Döll, P.: Mirca2000 - global monthly irrigated and rainfed crop areas around the year 2000: A new high-resolution data set for agricultural and hydrological modelling, Global Biogeochem. Сy., 24(1), GB1011, doi:10.1029/2008GB003435, available at: http://www.geo.uni-frankfurt.de/ipg/ag/dl/forschung/MIRCA/ data_download/index.html, last access: 15 October 2009, 2010.

Postel, S. L., Daily, G. C., and Ehrlich, P. R.: Human appropriation of renewable freshwater, Science, 271(5250), 785-788, 1996.

Reynolds, C. A., Yitayew, M., Slack, D. C., Hutchinson, C. F. Huete, A., and Petersen, M. S.: Estimating crop yields and production by integrating the FAO Crop Specific Water Balance model with real-time satellite data and ground-based ancillary data, Int. J. Remote Sens., 21(18), 3487-3508, 2000.

Rockström, J. and Barron, J.: Water productivity in rainfed systems: overview of challenges and analysis of opportunities in water scarcity prone savannahs, Irrigation Sci., 25(3), 299-311, 2007.

Rockström, J. and Gordon, L.: Assessment of green water flows to sustain major biomes of the world: Implications for future ecohydrological landscape management, Phys. Chem. Earth Pt. B, 26(11-12), 843-851, 2001.

Rockström, J., Gordon, L., Falkenmark, M., Folke, C., and Engvall, M.: Linkages among water vapor flows, food production, and terrestrial ecosystem services, Conserv. Ecol., 3(2), 5, available at:http://www.consecol.org/vol3/iss2/art5/, 1999.

Rockström, J., Barron, J., and Fox, P.: Water productivity in rain-fed agriculture: challenges and opportunities for smallholder farmers in drought-prone tropical agroecosystems, in: Water produc- 
tivity in agriculture: limits and opportunities for improvement, edited by: Kijne, J. W., CAB International, Wallingford, 315$352,2003$.

Rockström, J., Hatibu, N., Oweis, T. Y., Wani, S., Barron, J., Bruggeman, A., Farahani, J., Karlberg, L., and Qiang, Z.: Managing water in rainfed agriculture, in: Water for food, water for life: A comprehensive assessment of water management in agriculture, edited by: Molden, D., Earthscan, London, 315-352, $2007 \mathrm{a}$.

Rockström, J., Lannerstad, M., and Falkenmark, M.: Assessing the water challenge of a new green revolution in developing countries, P. Natl. Acad. Sci. USA, 104(15), 6253-6260, 2007 b.

Rockström, J., Falkenmark, M., Karlberg, L., Hoff, H., Rost, S., and Gerten, D.: Future water availability for global food production: the potential of green water for increasing resilience to global change, Water Resour. Res., 45, W00A12, doi:10.1029/2007WR006767, 2009.

Rohwer, J., Gerten, D., and Lucht, W.: Development of functional types of irrigation for improved global crop modelling, Potsdam Institute for Climate Impact Research, Potsdam, Germany, 2007.

Rosegrant, M. W. and Ringler, C.: Impact on food security and rural development of transferring water out of agriculture, Water Policy, 1(6), 567-586, 2000.

Rost, S., Gerten, D., Bondeau, A., Lucht, W., Rohwer, J., and Schaphoff, S.: Agricultural green and blue water consumption and its influence on the global water system, Water Resour. Res., 44, W09405, doi:10.1029/2007WR006331, 2008.

Rost, S., Gerten, D., Hoff, H., Lucht, W., Falkenmark, M., and Rockström, J.: Global potential to increase crop production through water management in rainfed agriculture, Environ. Res. Lett., 4, doi:10.1088/1748-9326/4/4/044002, 2009.

Roy, R. N., Misra, R. V, Lesschen, J. P., and Smaling, E. M. A.: Assessment of Soil Nutrient Balance. Approaches and Methodologies, FAO Fertilizer and Plant Nutrition Bulletin, 14, FAO, Rome, 2003.

Sacks, W. J., Deryn, D. G, Foley, J. A., and Ramankutty, N.: Crop planting dates: An analysis of global patterns, Global Ecol. Biogeogr., 19(5), 607-620, doi:10.1111/j.14668238.2010.00551.x, available at: http://www.sage.wisc.edu/ download/sacks/ArcINFO5min.html, last access: 9 September 2009, 2010.

Schuol, J. and Abbaspour, K. C.: Using monthly weather statistics to generate daily data in a SWAT model application to West Africa, Ecol. Model., 201, 301-311, 2007.
Seckler, D., Amarasinghe, U., Molden, D. J., de Silva, R., and Barker, R.: World water demand and supply, 1990-2025: Scenarios and issues, IWMI Research Report 19, IWMI, Colombo, Sri Lanka, 1998.

Siebert, S. and Döll, P.: The global crop water model (GCWM): Documentation and first results for irrigated crops. Frankfurt Hydrology Paper 07, Institute of Physical Geography, University of Frankfurt, Frankfurt am Main, Germany, available at: http://www.geo.uni-frankfurt.de/ipg/ag/dl/f_publikationen/ 2008/FHP_07_Siebert_and_Doell_2008.pdf, 2008.

Siebert, S. and Döll, P.: Quantifying blue and green virtual water contents in global crop production as well as potential production losses without irrigation, J. Hydrol., 384, 198-207, 2010.

Shiklomanov, I. A.: World fresh water resources, in: Water in crisis: A guide to the world's fresh water resources, edited by: Gleick, P. H., Oxford University Press, Oxford, UK, 13-24, 1993.

Shiklomanov, I. A.: Appraisal and Assessment of World Water Resources, Water Int., 25(1),11-32, 2000.

Shiklomanov, I. A. and Rodda, J. C. (Eds.): World water resources at the beginning of the twenty-first century, Cambridge University Press, Cambridge, UK, 2003.

Solley, W. B., Pierce, R. R., and Perlman, H. A.: Estimated Use of Water in the United States in 1995, USGS Circular 1200, US Geological Survey, Reston, USA, available at: http://water.usgs. gov/watuse, 1998.

UNDP: Beyond scarcity: power, poverty and the global water crisis, Human Development Report 2006, United Nation Development Program, 2006.

UNEP GEMS/Water Programme: Water Quality for Ecosystem and Human Health, 2nd Edn, UNEP GEMS/Water Programme, 2008 .

USDA: The major world crop areas and climatic profiles, Agricultural Handbook No. 664, World Agricultural Outlook Board, United States Department of Agriculture, available at: www.usda.gov/oce/weather/pubs/Other/MWCACP/ MajorWorldCropAreas.pdf, 1994.

Vörösmarty, C. J., McIntyre, P. B., Gessner, M. O., Dudgeon, D., Prusevich, A., Green, P., Glidden, S., Bunn, S. E., Sullivan, C. A., Liermann, C. R., and Davies, P. M.: Global threats to human water security and river biodiversity, Nature, 467(7315), 555$561,2010$. 